\title{
Wet Storage Integrity Update
}

W. J. Bailey

A. B. Johnson, Jr.

September 1983

Prepared for the U.S. Department of Energy under Contract DE-AC06-76RLO 1830

Pacific Northwest Laboratory Operated for the U.S. Department of Energy by Battelle Memorial Institute 


\title{
DISCLAIMER
}

This report was prepared as an account of work sponsored by an agency of the United States Government. Neither the United States Government nor any agency thereof, nor any of their employees, makes any warranty, express or implied, or assumes any legal liability or responsibility for the accuracy, completeness, or usefulness of any information, apparatus, product, or process disclosed, or represents that its use would not infringe privately owned rights. Reference herein to any specific commercial product, process, or service by trade name, trademark, manufacturer, or otherwise, does not necessarily constitute or imply its endorsement, recommendation, or favoring by the United States Government or any agency thereof. The views and opinions of authors expressed herein do not necessarily state or reflect those of the United States Government or any agency thereof.

\author{
PACIFIC NORTHWEST LABORATORY \\ operated by \\ BATTELLE \\ for the \\ UNITED STATES DEPARTMENT OF ENERGY \\ under Contract DE-AC06-76RLO 1830
}

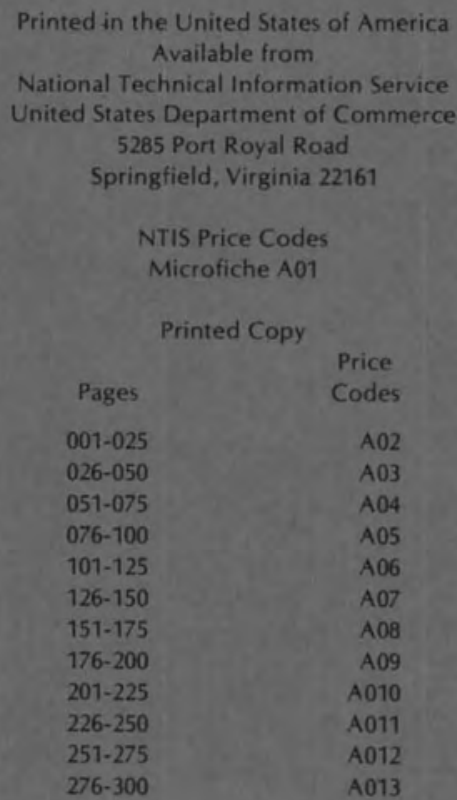


PNL-4726

UC-85

WET STORAGE INTEGRITY UPDATE

W. J. Bailey

A. B. Johnson, Jr.

September 1983

Prepared for

the U.S. Department of Energy

under Contract DE-AC06-76RLO 1830

Pacific Northwest Laboratory

Richland, Washington 99352 


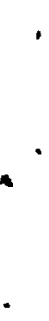




\section{ABSTRACT}

This report includes information from various studies performed under the Wet Storage Task of the Spent Fuel Integrity Project of the Commercial Spent Fuel Management (CSFM) Program at Pacific Northwest Laboratory. An overview of recent developments in the technology of wet storage of spent water reactor fuel is presented. Licensee Event Reports pertaining to spent fuel pools and the associated performance of spent fuel and storage components during wet storage are discussed. The current status of fuel that was examined under the CSFM Program is described. Assessments of the effect of boric acid in spent fuel pool water on the corrosion and stress corrosion cracking of stainless steel and the stress corrosion cracking of stainless steel piping containing stagnant water at spent fuel pools are discussed. A list of pertinent publications is included. 


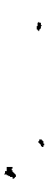

4 


\section{SUMMARY}

The U.S. Department of Energy, recognizing the importance of wet storage to spent fuel management, is sponsoring the Spent Fuel and Pool Component Integrity Project at Pacific Northwest Laboratory. This report is the third in a series of periodic updates summarizing published results and including results from smaller subtasks not previously published.

Project subtasks include:

- Spent Fuel Surveillance

This subtask has included examinations of selected light-water reactor fuel to investigate whether wet storage promotes cladding degradation.

- Spent Fuel Pool Component Examinations

This subtask has involved examinations of sections from stainless steel and aluminum storage pool components (racks, liners, etc.).

- Stainless Steel Stress Corrosion Cracking Investigations This subtask has involved investigations of instances of intergranular stress corrosion cracking in piping at several pressurized water reactor spent fuel pools and in fuel assembly hardware. 


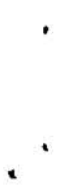

เ 


\section{CONTENTS}

ABSTRACT.

SUMMARY.

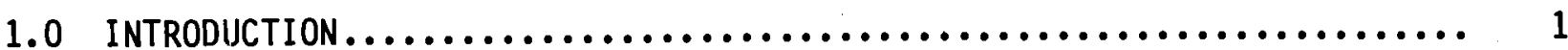

2.0 CONCLUSIONS AND RECOMMENDATIONS $\ldots \ldots \ldots \ldots \ldots \ldots \ldots \ldots \ldots \ldots \ldots \ldots$

3.0 OVERVIEW OF RECENT DEVELOPMENTS....................... 7

3.1 WORLD SURVEY OF EXPERIENCE ON STORAGE OF WATER

REACTOR SPENT FUEL IN WATER POOLS..................... 7

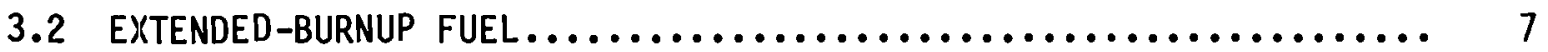

3.3 ROD CONSOLIDATION............................. 9

3.4 DOUBLE TIERING OF SPENT FUEL STORAGE RACKS ............... 11

4.0 SPENT FUEL AND STORAGE COMPONENT PERFORMANCE................. 13

4.1 SPENT FUEL HANDLING............................ 13

4.2 SPENT FUEL POOL EQUIPMENT MALFUNCTIONS $\ldots \ldots \ldots \ldots \ldots \ldots \ldots \ldots \ldots$

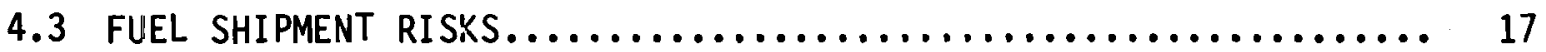

5.0 STATUS OF EXAMINED FUEL $\ldots \ldots \ldots \ldots \ldots \ldots \ldots \ldots \ldots \ldots \ldots \ldots \ldots \ldots \ldots \ldots \ldots$

5.1 SHIPPINGPORT FUEL $\ldots \ldots \ldots \ldots \ldots \ldots \ldots \ldots \ldots \ldots \ldots \ldots \ldots \ldots \ldots \ldots \ldots \ldots \ldots \ldots$

5.2 CONNECTICUT YANKEE FUEL ASSEMBLY SO04................. 21

5.3 INSPECTION OF FAILED OCONEE FUEL $\ldots \ldots \ldots \ldots \ldots \ldots \ldots \ldots \ldots \ldots \ldots \ldots$

6.0 ASSESSMENT OF FUEL IMPURITIES IN BORIC ACID ................ 39

7.0 ASSESSMENT OF STRESS CORROSION CRACKING OF STAINLESS STEEL

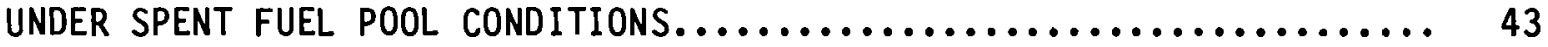

8.0 ASSESSMENT OF STRESS CORROSION CRACKING OF STAINLESS STEEL

PIPING CONTAINING STAGNANT WATER AT SPENT FUEL POOLS ............ 45

8.1 PROCEDURE...................................... 45

8.2 DATA AND RESULTS $\ldots \ldots \ldots \ldots \ldots \ldots \ldots \ldots \ldots \ldots \ldots \ldots \ldots \ldots \ldots \ldots \ldots$

8.3 DISCUSSION..................................... 49 
9.0 INSPECTION OF SPENT FUEL STORAGE FACILITY AT THE BARNWELL PLANT..... 53

9.1. POOL HISTORY AND MATERIALS.......................... 53

9.2 MATERIALS EXPERIENCE AT THE BARNWELL FUEL STORAGE

FACILITY...................................... 53

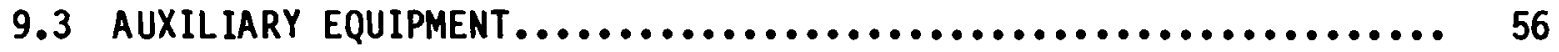

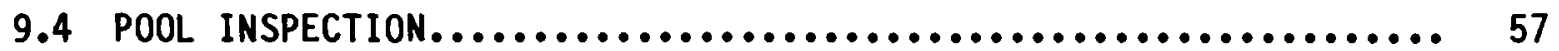

9.4 .1 Stainless Steel............................. 57

9.4 .2 Aluminum Alloys............................. 57

10.0 REFERENCES........................................... 59

APPENDIX--PUBLICATIONS................................... A.1 


\section{FIGURES}

1 Prairie Island-1 Fuel Assembly That Had the Top End Fitting Separate from the Remainder of the Assembly During Spent Fuel

Pool Handling Operations.............................. 15

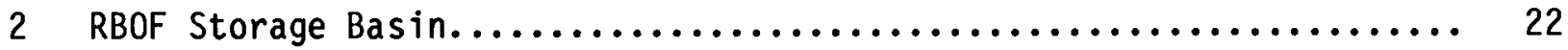

3 Location of Shippingport Fuel in RBOF Storage Basin............ 22

4 Shippingport Fuel in Storage Basket in RBOF "Repack Basin"........ 23

5 Shippingport Fuel at a Raised Leve1 in the "Repack Basin"........ 23

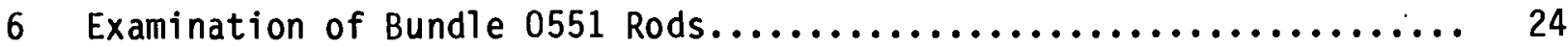

7 Schematic of Connecticut Yankee Fuel Assembly SO04, Including Details of Thimble Tube Weld Areas........................... 24

8 Metallography Showing the Heat-Affected Zone of End Cap Weld Areas from Connecticut Yankee Assembly SO04 Fuel Rods...............

9 Macrograph of As-Polished Surface from Rod AHR from Assembly SOO4 at 56.76 in. Above the Bottom of the Rod..................... 26

10 Rod Transfers That Have Been Made in Assembly s004.............. 32

11 Planned Final Loading of Rods in Assembly S004................ 32

12 Periscope Photographs of Fuel Assembly 1A10 Showing the Large Defect in Rod C14.....................................

13 Postirradiation Equipment in the Oconee Spent Fuel Pool with Fuel As sembly 1 A10 Being Gamma Scanned.......................... 36

141982 Periscope Photographs of Fuel Assembly 2B47 Showing that Crud, Which Appeared Adherent in 1978, Now Exhibits Flakiness and a Tendency to Peet....................................... 38

15 Apparatus for Conducting Stagnant Pipe Tests................. 46

16 Dissolved Oxygen Concentration at the Pipe Wall.............. 48

17 Dissolved Oxygen Concentration at the Pipe Centerline.......... 48

18 Solution $\mathrm{pH}$ at Both the Pipe Wall and Centerline............... 49

19 Barnwell Fuel Storage Facility........................... 54 
20 Aluminum Fuel Storage Canister on Aluminum Rack................ 58

21 Barnwell Fuel Storage Facility with Water Removed............... 59 
$\underline{\text { TABLES }}$

1 Alternatives for Increasing the Storage Capacity of Existing Spent Fuel Storage Pools With and Without Rod Consolidation......... 12

2 Storage Densities and Spent Fuel Assembly Center-to-Center Spacings for Various Rack Types in Spent Fuel Storage Pools......... 12

3 Summary of Characterizations on Fuel Rods From Assembly S004........ 30

4 Five Unfailed Fuel Rods From Assemblies Gll and HO7 to be Inserted in Assembly S004....................................... 31

5 Oconee Fuel Assemblies with Defective Fuel Rods................... 34

6 PWR Spent Fuel Pool Water Quality Specifications................... 40

7 Analysis of Boric Acids...................................... 41

8 Chemical Analysis of Stainless Steel Pipe and End Plates............ 46

9 Stagnant Pipe Initial Solution Chemistry....................... 47

10 Barnwell Pool History and Materials........................... 55

11 Water Quality Control and Operating Conditions.................. 56 


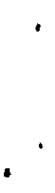

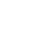

. 


\subsection{INTRODUCTION}

The performance of spent light-water reactor (LWR) fuel and storage components (for example, storage racks, piping, pool liners) during fuel storage in water-filled spent fuel pools has been the subject of studies at Pacific Northwest Laboratory $(P N L) .(a)$ Currently, those studies are conducted under the wet Storage Task of the Spent Fuel Integrity Project of the Commercial Spent Fuel Management (CSFM) Program at PNL. Two annual reports $(1,2)$ were published earlier, summarizing the results from PNL wet storage studies. The purpose of this report is to supplement the earlier periodical reports by summarizing subsequent results and by reporting information not previously published. A list of publications is provided in the appendix.

Briefly, the status of wet storage is as follows:

- The fïrst wet storage of irradiated fuel occurred in 1943 . Wet storage technology has been adaptable to a variety of fuel and reactor types. Wet storage of fuel has proceeded without major problems.

- Currently (1983), wet storage is the only licensed spent fuel management technology in the United States.

- Wet storage will remain an essential part of the water reactor spent fuel management as long as reactors operate.

- A recent publication(3) by the International Atomic Energy Agency (IAEA) summarized the world status of wet storage technology.

(a) Operated for the U.S. Department of Energy (DOE) by Battelle Memorial Institute. 


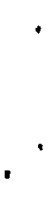

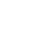

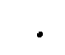

.

. 


\subsection{CONCLUSIONS AND RECOMMENDATIONS}

The IAEA world survey ${ }^{(3)}$ concluded that wet storage is an essential technology for the duration of water reactor operation (as well as for some gascooled reactors)--even with dry storage and/or reprocessing. Wet storage is the only spent fuel management technology licensed in the United States and some other countries. The survey indicates that a strong basis exists for concluding that wet storage of spent fuel is a mature, viable technology free of major technological difficulties and that spent fuel pool operations proceed without substantial hazard to plant personnel or the public. Zircaloy-clad and stainless steel (SS)-clad fuel have resided in pools for 21 years and $\sim 12$ years, respectively, without evidence of pool-induced degradation. There have been only minor problems with spent fuel pool components; for example, pressurized water reactor (PWR) pipe weld cracking, expansion of storage rack panels against fuel assemblies, and pool liner leaks. The radiation doses and waste volumes from spent fuel pool operations are small relative to other reactor operations. The survey concludes that continuing successful application of wet storage is essential.

To date, there is no evidence that extended burnup will lead to degradation of spent LWR fuel during wet storage, based on current water reactor fuel storage experience and assessments of the impacts of extended burnup on fuel characteristics. Even if extended burnup results in some number of in-reactor fuel failures, pool storage technology has a demonstrated capability to deal with them.

The favorable experience in spent fuel handling and reconstitution operations should extend to rod consolidation. Consolidated fuel can be safely stored in racks of existing designs; however, in some cases, it may not be possible to comply with the licensing requirement for criticality safety unless additional fixed neutron absorbers are installed or a licensed method to verify fuel burnup becomes available. While there has been no experience with extended wet storage of consolidated rods, a recent demonstration was performed in the United States that involved the consolidation of irradiated fuel. 
Utilities are examining options for increasing the capacities of their spent fuel storage pools. Many pools have already been reracked more than once, and at least three spent fuel pools employ double tiers of racks. However, static loading constraints are especially restrictive for boiling water reactors (BWRs) with elevated spent fuel storage pools.

Some abnormal events have occurred involving a total of several hundred domestic and foreign fuel assemblies. However, major mechanical damage has occurred in very few assemblies as a result of handling operations and very few assemblies are known to have sustained damage from normal transport. The separation of the top end fitting (nozzle) from the remainder of a spent Prairie Island-1 fuel assembly during handling operations at the spent fuel storage pool involved failure of SS sleeves at bulge joints. This incident was the first such occurrence reported to the U.S. Nuclear Regulatory Commission (NRC). The contaminant that caused the intergranular stress corrosion cracking (IGSCC) of the sleeves and its source have not yet been identified. Intrusion of sulfur is a possibility, but the NRC indicates that there is no evidence to date that sulfate contamination caused the corrosion. The NRC has concluded that the Prairie Island fuel assembly corrosion is an isolated incident and does not have generic implications. The NRC also concluded that current guidelines for primary and spent fuel pool water chemistry specifications and monitoring techniques are adequate.

Zircaloy-clad fuel rods (some of which have been in wet storage for 23 years) from Shippingport and SS-clad fuel rods(a) from the Connecticut Yankee qualification fuel assembly (in wet storage for $\sim 8$ years) will be available for periodic surveillance and examinations in the future, if warranted. The nondestructive examination (NDE) of the defective fuel rods in the five 0conee fuel assemblies (in wet storage for 5 to 8 years) revealed no significant changes to the integrity of the defective rods that could be attributed to wet storage. Between the examinations in 1978 and 1982, the crud (i.e., corrosion product deposit) underwent some changes--it appeared rather adherent in 1978 but was flaky and had a tendency to peel off in 1982.

(a) Fifteen rods are well characterized. 
While conducting SCC studies at PNL, it was observed that some boric acid lots contain certain impurities. At PWRs, boric acid is added to the spent fuel pool water.

Two recent cases illustrate the fact that Type 304 SS is subject to IGSCC under spent fuel pool conditions.

A stagnant pipe test was conducted by PNL to investigate oxygen and $\mathrm{pH}$ changes under stagnant conditions. Results indicated that a decrease of $\sim 4 \mathrm{ppm}$ in dissolved oxygen concentration is accompanied by a small increase $(0.35)$ in pH.

We need to continue to be aware of and to monitor developments in:

- cracking of SS components (such as sleeves attached to top end fittings) of certain PWR fuel assemblies

- cracking of PWR pipe

- swelling of storage rack panels

- possible effects of extended burnup

- other miscellaneous, significant, or relevant events at spent fuel storage pools and at other facilities where spent fuel is handled. 


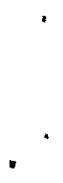




\subsection{OVERVIEW OF RECENT DEVELOPMENTS}

\subsection{WORLD SURVEY OF EXPERIENCE ON STORAGE OF WATER REACTOR SPENT FUEL IN WATER POOLS}

The IAEA in Vienna, Austria, and the Organization for Economic Cooperation and Development/Nuclear Energy Agency (OECD/NEA) in Paris, France, cooperated on a world survey of wet storage experience. The report ${ }^{(3)}$ summarizing the survey includes information on the following topics.

- spent fuel history

- spent fuel behavior

- pool characteristics and water chemistry

- pool equipment behavior

- measures to control radiation doses and waste volume

- pool design and operational innovations

- spent fuel surveillance procedures and results.

The report is available in Austria from the IAEA (P.0. Box 100, A-1400, Vienna, Austria) or in the United States from UNIPUB (P.0. Box 433, Murray Hill Station, New York, NY 10016). A summary (4) of the world survey was presented at the IAEA Seminar on Technical and Environmental Aspects of Spent Fuel Management in Madrid, Spain, September 1983.

\subsection{EXTENDED-BURNUP FUEL}

Extended burnup is presently an important emerging concept in the LWR fuel cycle. BWR and PWR fuels currently have design and warranty burnups of $\sim 28 \mathrm{MWd} / \mathrm{kgU}$ and 33 to $36 \mathrm{MWd} / \mathrm{kgU}$, respectively. (5) Optimal extended burnups (discharge batch averages) are typically $45 \mathrm{MWd} / \mathrm{kgU}$ and $50 \mathrm{MWd} / \mathrm{kgU}$ for BWRs and PWRs, respectively, on a 12-month refueling cycle. (6) If 18-month refueling cycles are assumed, the optimal burnup values are $\sim 10 \%$ higher. It appears that fuel designed for extended burnup will not become available for full reloads until the late 1980s; in the interim there will be a gradual increase of 1 to $2 \mathrm{MWd} / \mathrm{kgU}$ per vear in burnup. (7)

The effect of extended burnup on interim spent fuel storage is described in References 8 and 9 . Factors evaluated included: the extended-burnup 
effects on spent fuel inventories and spent fuel characteristics; fuel enrichment considerations; the current basis for spent fuel storage evaluations; and storage surveillance for extended-burnup fuel.

Extending fuel burnup has a favorable impact on the spent fuel inventory: it reduces the rate at which spent fuel accumulates, which lowers storage requirements. Fewer fuel assemblies per reload are required if fuel is irradiated for four or five cycles instead of three, and the result is that spent fuel storage requirements could be reduced by as much as $40 \%$. (10)

Current extended-burnup fuel designs have higher initial enrichment, which may necessitate changes in storage racks and/or methods. Many spent fuel storage facilities use racks that have been optimized for fuel of current enrichments to maximize the capacities of the facilities, while continuing to comply with present regulatory requirements. The NRC regulatory guide(11) and the approved standard, ANSI/ANS-57.7-1981, (12) permit credit for fuel burnup in the calculation of the effective multiplication factor $\left(k_{e f f}\right)$ for storage rack designs, but there is no licensed method presently operational for verifying fuel burnup in a spent fuel storage pool.(13)

The spent fuel characteristics considered in References 8 and 9 were cladding oxide films, corrosion product (crud) layers, and hydrogen contents; cladding mechanical properties; fuel failure rates; and fission product inventories. It was concluded that there is no evidence to date that extended burnup will lead to degradation of spent LWR fuel during wet storage, based on current water reactor fuel storage experience and assessments of extendedburnup impacts on fuel characteristics. Anticipated changes in fuel assembly characteristics resulting from extended burnup are not expected to have a significant adverse effect on fuel cladding integrity during subsequent storage in water. Even if extended burnup results in some number of in-reactor fuel failures, pool storage technology has a demonstrated capability to deal with them. The availability of well-characterized extended-burnup fuel assemblies offers a cost-effective opportunity to obtain additional evidence of spent fuel behavior in wet storage. 
Storage of extended-burnup fuel has been made an issue by nuclear intervenors. (14) However, if direct supporting evidence is available, the hearing process can frequently be shortened.

\subsection{ROD CONSOLIDATION}

Rod consolidation involves removing rods from a fuel assembly for placing them in a closer packed array in a gridded or ungridded container. Thus, rod consolidation reduces the space per unit weight of fuel requiring storage, resulting in more efficient use of existing storage space, a decrease in the size and cost of new storage facilities, and lower shipping costs. (15)

Two operations that are now performed routinely are similar to those associated with rod consolidation: 1) rod removal (for example, for nondestructive testing or repair) and 2) fuel assembly reconstitution (repairing assemblies for return to reactor service by removing and replacing defective rods). Experience with rod removal and fuel assembly reconstitution has been described by several authors. (16-23) The relationship of the extensive experience with fuel handling and reconstitution to rod consolidation and the effects of consolidation on rod integrity are discussed in Reference 16. Many fuel assemblies and fuel rods have been handled; $(24,25)$ in the United States, over 51,000 fuel rods have been removed from fuel assemblies for inspection or repair purposes. Several thousand BWR and PWR fuel assemblies have been successfully reconstituted in the United States and in other countries and returned to reactor service. Very few fuel assemblies have sustained major mechanical damage as a result of handling operations at the reactor or the spent fuel storage pool.(24-27) In most of the several hundred domestic and foreign fuel assemblies damaged to date, only minor degradation of the fuel assembly components has been observed. This favorable experience in spent fuel handling and reconstitution operations should extend to rod consolidation. It is also anticipated that the handing experience with higher burnup fuel will be similar, based on limited experience. (1.6)

Aspects of rod removal operations to be considered in fuel rod integrity evaluations include scratches on fuel rod surfaces, rod breakage, and crud effects. Increased temperature (a result of close-packing rods in a container), 
formation of crevices, and galvanic effects are other considerations. No problems are expected. While there has been no experience with wet storage of consolidated rods for an extended period, (27) a recent consolidation demonstration was conducted on irradiated fue $1 .(28)$

Criticality analyses $(13,29-31)$ have evaluated the effect of introducing consolidated fuel rods in containers (gridded or ungridded) into spent fuel storage pools. Because of rod distortion (bowing) and other effects, consolidated rods will probably be in a looser, more irregular array in the container instead of an idealized close-packed array. Such arrangements, however, are quite subcritical (keff $<0.95) .(30,31)$ The reactivity of a completely filled container is less than that of a standard fuel assembly, but the reactivity of the container is a function of the number of rods in it. As a result, for spent fuel storage racks that store consolidated fuel rods, the limiting case-and, fortunately, one that is highly unlikely to occur--would be a rack loaded with partially filled, optimally moderated containers. (13)

Accidents with consolidated fuel could result in some fuel rod rearrangements that could become supercritical. The most severe case appears to involve spilling rods (as few as 100) from a container into the racks of stored spent fuel in a pool. (31) During handling operations at a spent fuel storage pool in 1975, a BWR fuel assembly was inadvertently dropped because of improper grappling. When it was subsequently pulled to a vertical position, all the fuel rods fell from the assembly and into the spent fuel cask pit. ${ }^{(32,33)}$ Several mechanical means have been suggested $(31)$ to prevent fuel rod rearrangements during consolidation operations, including inserting spacers to exclude fuel rods from rack (and shipping cask) cavities and employing careful mechanical designs to ensure integrity of fixed poisons and containers.

Consolidated fuel can be safely stored in racks of existing designs. In some cases, however, it may not be possible to meet the licensing requirement for criticality safety unless additional fixed neutron absorbers are installed or a licensed method to verify fuel burnup becomes available. (13)

Safeguards issues that might arise in licensing rod consolidation were investigated in a recent study.(15) A major concern involves the ability to 
1) accurately establish the amount of nuclear fuel present in each consolidation container and 2) provide a means to verify, on a routine basis at appropriate intervals, that the fuel continues to reside in the container. Ways to achieve these objectives and yet avoid accountability on a rod basis (an advantage because it is difficult to identify the serial number on each rod after irradiation) are described. Until rod consolidation is licensed, however, there is no guarantee that the methods and procedures described in the study will be accepted by the regulatory agencies. ${ }^{(31)}$

In mid-1983, efforts were initiated to develop ANS-57.10, "Criteria for LWR Fuel Rod Consolidation." Rod consolidation is not licensed at U.S. plants; however, unfueled demonstrations have been conducted. The NRC has reviewed an application from Maine Yankee and has issued a Safety Evaluation and Environmental Impact Appraisal. (34) Recently, the first U.S. consolidation of irradiated LWR fuel was demonstrated by Duke Power Company and Westinghouse Electric Corporation at the Oconee Nuclear Station. (28)

\subsection{DOUBLE TIERING OF SPENT FUEL STORAGE RACKS}

Spent commercial LWR fuel is typically stored in water-filled, SS-lined concrete basins. The fuel assemblies are stored vertically in aluminum or SS racks. Utilities are currently examining the options, shown in Table 1, to expand capacities of existing spent fuel storage pools. Second tiers of racks may be installed if the pool is deep enough and if the structure can cope with the added static load.(15) Static loading constraints are especially restrictive for BWRs with elevated pools--they are not built on bedrock. $(15,27)$ With some LWRs, seismic loads are the limiting restriction.

Many utility spent fuel pools have already been reracked more than once. (27) Spent fuel storage densities for various rack types and the associated center-to-center spacings of the spent fuel assemblies are shown in Table 2.

The following spent fuel pools utilize double tiering: the Atucha-1 pool (Argentina), (35) the Yankee Rowe pool, ${ }^{(36)}$ and the LaCrosse pool. 
TABLE 1. Alternatives for Increasing the Storage Capacity of Existing Spent Fuel Storage Pools With and Without Rod Consolidation $(15,27,37)$

- Increase the capacity of existing racks

- Add racks to the existing array

- Rerack with absorber racks

- Double tiering (install a second tier of racks over those on the pool floor)

- Transshipment (ship fuel between reactor pools at different sites)

TABLE 2. Storage Densities and Spent Fuel Assembly Center-to-Cęnter Spacings for Various Rack Types in Spent Fuel Storage Pools 37 )

\begin{tabular}{|c|c|c|}
\hline Rack Type/Material & $\begin{array}{l}\text { Storage Density, } \\
\mathrm{MgU} / \mathrm{m}^{2}\left(\mathrm{MgU} / \mathrm{ft}^{2}\right)\end{array}$ & $\begin{array}{l}\text { Fuel Assembly } \\
\text { Center-to-Center } \\
\text { Spacing, cm (in.) }\end{array}$ \\
\hline $\begin{array}{l}\text { Low-density/aluminum or } \\
\text { stainless steel }\end{array}$ & $0.023(0.25)$ & $\begin{array}{l}\text { Up to } 33(13) \text { for BWR fuel } \\
\text { and } 56(22) \text { for PWR fuel }\end{array}$ \\
\hline $\begin{array}{l}\text { High-density (HD)/stainless } \\
\text { steel }\end{array}$ & $0.036(0.39)$ & $\begin{array}{l}\text { As } 1 \text { low as } 20(8) \text { for BWR } \\
\text { fuel and } 33(13) \text { for PWR } \\
\text { fuel }\end{array}$ \\
\hline $\begin{array}{l}\text { Poisoned HD/stainless steel } \\
\text { with added neutron absorber }\end{array}$ & $0.054(0.58)$ & $\begin{array}{l}16.5(6.5) \text { for BWR fuel } \\
\text { and } 26.7^{(10.5)} \text { for PWR } \\
\text { fue } 1\end{array}$ \\
\hline $\begin{array}{l}\text { Double-tier HD/stainless } \\
\text { steel }\end{array}$ & $0.072(0.78)$ & -- \\
\hline
\end{tabular}




\subsection{SPENT FUEL AND STORAGE COMPONENT PERFORMANCE}

\subsection{SPENT FUEL HANDLING}

In the United States, tens of thousands of fuel assemblies have been successfully and safely moved during normal handling operations at reactors and spent fuel storage pools. Over 51,000 fuel rods have been removed from assemblies for inspection or repair, and over 5100 assemblies have been shipped. In the United States and other countries, several thousand assemblies have been reconstituted (rods removed and replaced) and subsequently returned to reactor service. Some abnormal events involving a total of several hundred U.S. and non-U.S. fuel assemblies have occurred, but very few fuel assemblies have suffered major mechanical damage as a result of handling operations or are known to have sustained damage from normal transport. $(16,24-26,38)$

Most handling incidents have generally involved only minor damage to the fuel assembly components and no breaching of the fuel cladding or release of radioactive gases or solids. The experience with handling operations at spent fuel pools indicates that failed fuel rods and inadvertent breaking of fuel rods (including prepressurized ones) can be accommodated. (39) The complete breaking of a PWR fuel assembly in a spent fuel storage pool has been simulated in a French experiment. (40) PNL's 1 iterature survey (24-26) indicates that during handling operations, 34 assemblies ( 31 domestic and 3 foreign) have been dropped; 3 assemblies ( 2 domestic and 1 foreign) have fallen from a vertical to a horizontal position; 3 assemblies (all domestic) have tilted a few tens of degrees from vertical and have come to rest against another object; a few fuel rods have been fractured; some rods have been dropped; and upper end fittings (top nozzles) have separated from three PWR fuel assemblies. Tack weld failures caused the nozzles to separate from two Indian Point-1 assemblies(41) about a decade ago, but a December 1981 incident in which the nozzle separated from a Prairie Island-1 assembly involved a different cause as noted below.

The top nozzle separated from the remainder of the spent Prairie Island-1 fuel assembly as it was being lifted out of a storage rack in the spent fuel p001; the assembly was being transferred from the Prairie Island-2 pool to the Prairie Island-1 pool.(42-45) This PWR fuel assembly, which was manufactured 
by Westinghouse Electric Corporation, was discharged in April 1979 with a burnup of $29 \mathrm{MWd} / \mathrm{kgU}$. The assembly was subsequently placed in the Prairie Island-2 spent fuel pool, where it remained in wet storage for 43 months. No radiation releases and no fuel rod damage occurred. The fuel assembly was subsequently lifted and inserted into a storage position.

The mode of failure was identified as IGSCC of the Type 304 SS sleeves (Figure 1), which were welded to the top nozzle and mechanically joined to the Zircaloy control rod guide thimbles (the sleeves and thimbles are the loadbearing members when the vertically positioned assembly is lifted by pulling on the top nozzle). The Zircaloy guide thimbles (tubes) appear to have remained intact. The SCC is believed to have occurred in the spent fuel pool and had not been anticipated. Apparently, the pool chemistry met specifications reasonably well during the storage period. ${ }^{(43)}$ The contaminant that caused the IGSCC and its source have not been identified yet; however, sulfate contamination was highly suspected. ${ }^{(46)}$

Westinghouse has substantial experience at various plants with $\sim 5000$ fuel assemblies with this type of SS-to-Zircaloy joint. ${ }^{(44)}$ Westinghouse performed postirradiation examinations of fuel assemblies at Prairie Island and television examinations of fuel assemblies at Trojan, Kewaunee, Point Beach (these three have the same fuel assembly design as Prairie Island), and Zion. (44) The same material lot was used in fuel assemblies at Prairie Island, Point Beach, and Kewaunee. Results from the television examinations at all plants except Prairie Island showed no evidence of SCC in the top nozzle. At Prairie Island, 27 assemblies were examined; 12 showed evidence of corrosion, but there were no additional nozzle failures when the assemblies were moved. In the one case in which the nozzle broke off, ${ }^{(44)}$ examination of the fracture surface revealed the presence of iron, chromium, aluminum, silicon, nickel, copper, chlorides, fluorides, and sulfur. The SCC is not considered to have occurred in the reactor because the hydrogen overpressure should have resulted in low free oxygen. However, the spent fuel pool has oxygen-saturated water at low temperature, which could cause cracking in the presence of high stresses and sensitized stainless steel. The NRC also evaluated the event $(45)$ and drew the following 


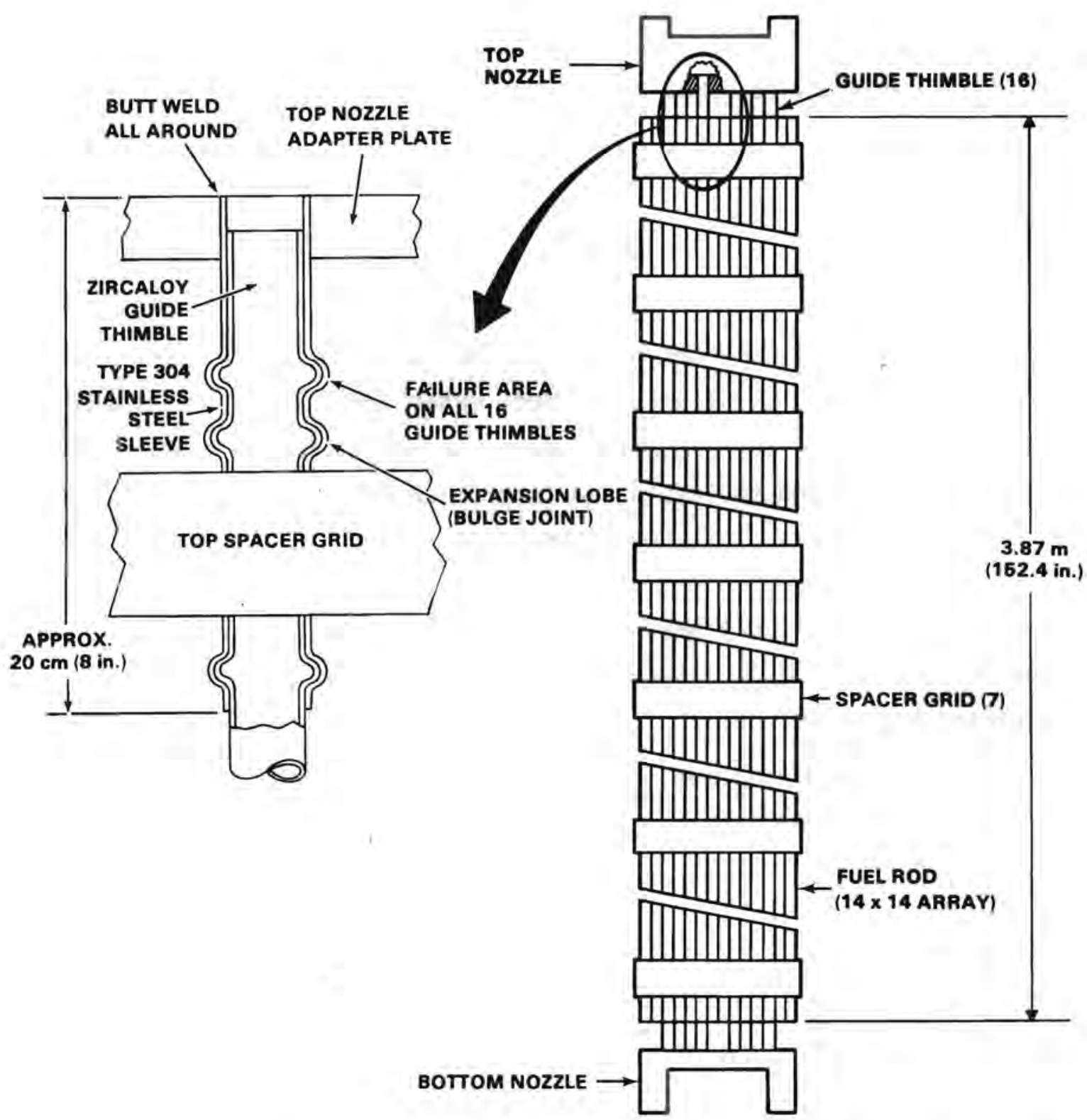

FIGURE 1. Schematic of Prairie Island-1 Fuel Assembly That Had the Top End Fitting (nozzle) Separate from the Remainder of the Assembly During Spent Fuel Pool Handling Operations. The length of the sleeves is $20 \mathrm{~cm}$ ( $8 \mathrm{in}$.). 
conclusions: 1) the failure mode of the Type 304 SS sleeves has been identified, but the root cause appears to be unresolved; 2) the mode of degradation appears to be new to fuel assemblies and probably occurred in the spent fuel pool; 3) the degradation may not be readily detectable; and 4) the degradation may be generic with the potential for dropped fuel assemblies and resultant fission product release. In the NRC safety evaluation report (47) it was concluded that the Prairie Island fuel assembly corrosion is an isolated incident and does not have generic implications. The report also indicates that current guidelines on primary and spent fuel pool water chemistry specifications and monitoring techniques are adequate. Very recently, the NRC proposed $(46)$ that consideration be given to issuing an Inspection and Enforcement (I\&E) Information Notice because the failure of the bulge joint in the Prairie Island-1 fuel assembly was the first time such an incident had been reported and because the contaminant and its source have not been identified. Although intrusion of sulfur(a) is a possibility, there is no evidence to date that sulfate contamination caused the corrosion. (46)

Substantial radionuclide releases were associated with two dry shipments (one in France and one in the United States) of SS-clad PWR fuel. The French shipment involved four spent fuel assemblies from Chooz (SENA) that were apparently intact before shipment but were from a lot that had experienced fuel failures during in-reactor service. $(2,26,38,48)$ The U.S. shipment involved one Connecticut Yankee (Haddam Neck) fuel assembly that was known to contain failed fuel rods; the assembly was not canned before shipment. Airborne contamination was released during the underwater unloading of the assembly from the shipping cask. $(48,49)$

\subsection{SPENT FUEL POOL EQUIPMENT MALFUNCTIONS}

The lists of Licensee Event Reports published by the NRC in the NUREG/ CR-2000 report series in 1981 and 1982 included some cases associated with incidents involving spent fuel storage pool components at domestic plants. In three cases, the spent fuel storage pool was drained below the specified

\footnotetext{
(a) In contrast to chloride-induced SCC, sulfur-induced IGSCC of sensitized
austenitic alloys can proceed rapidiy at room temperatures.
} 
level; (a) and, in two cases, the spent fuel pool was overfilled.(b) In one case, storage rack samples exhibited swelling. In two cases, cracks were found in the spent fuel pool cooling system vent lines. In one case, the Type 416 SS bolts in spent fuel pool cooling pumps containing borated water were replaced because of corrosion and breakage. In one case, old spent fuel storage racks that were awaiting shipment to a disposal site contaminated dirt and stones in a storage area. The spent fuel pool negative pressure boundary was violated several times at one PWR; in 1981 (two times) and in 1982 (three times) the spent fuel pool ventilation system at this PWR failed to draw negative pressure because of open doors. The causes were: installation error (two cases), personnel error (one case), and faulty door closure mechanisms (two cases). At a BWR in September 1982, a fuel assembly was found to be attached to its fuel support piece and the two could not be separated. As a result, the assembly and the attached support piece were moved to the spent fuel pool using the refueling trolley grapple. The assembly could not be transferred to the spent fuel pool by normal methods because of the attached support piece.

\subsection{FUEL SHIPMENT RISKS}

Although the public has expressed concern over shipping spent fuel, an NRC report ${ }^{(50)}$ shows that the risk to the public is small. Truck casks and rail casks have been used in the United States to transport LWR fuel. During the last 20 years, over 5100 spent fuel assemblies have been shipped from commercial LWRs in the United States, and the safety record has been excellent. (51) About $70 \%$ of those spent fuel assemblies were shipped to storage and reprocessing facilities; those shipments involved a total of 2.03 million cask-miles. $(52,53)$ of the other $30 \%, 29 \%$ were associated with shipments between reactor spent fue 1 pools and $1 \%$ with shipments from reactors to experimental or hot cell facilities. ${ }^{(51)}$

(a) The technical specifications require a certain depth of water--typically $7 \mathrm{~m}$ or $23 \mathrm{ft}$--to be maintained over spent fuel in the pool. In one case, the pool was $-0.4 \mathrm{~m}$ (15 in.) below the specified level; and, in another case, it was $0.6 \mathrm{~m}(2 \mathrm{ft})$ below.

(b) In one case, the spilled volume was $87 \mathrm{~m}^{3}(23,000 \mathrm{gal})$. This spill in February 1982 was caused by the improper installation of a hose clamp on a temporary hose connection between two spent fuel pools. 



\subsection{STATUS OF EXAMINED FUEL}

\subsection{SHIPPINGPORT FUEL}

Zircaloy-clad fuel rods from two bundles (0551 and 0074) of Shippingport PWR Core 1 blanket fuel were metallurgically examined by PNL in 1980 and 1981 after extended storage in water. Bundle 0551 was the world's oldest poolstored, Zircaloy-clad fuel: it had been stored for nearly 21 years in deionized water. Bundle 0074 had been stored for 16 years in deionized water. The examination was performed for PNL by Battelle-Columbus Laboratories (BCL) at the $B C L$ hot cell facility in West Jefferson, Ohio. Fifteen fuel rods from Bundle 0551 and Bundle 0074 (total of 120 fuel rods) arrived at the BCL facility in July 1980. Examination results have been published in PNL-3921 ${ }^{(54)}$ and el sewhere. $(1,2,55,56)$

Fuel rod and cladding characteristics from the recent PNL examination were compared with those from past examinations on the same and similar Shippingport fuel. No significant degradation of the Zircaloy cladding was detectable after almost 21 years in wet storage. The cladding dimensions and mechanical properties, fission gas releases, hydrogen content of the cladding, and external oxide film thicknesses that were measured during the recent examination were all within the range of measurements made on fuel rods from one of the same bundles soon after reactor discharge. Appearances of the external surfaces and microstructures of the fuel and cladding were also similar to those reported previously. No evidence of accelerated corrosion or hydride redistribution in the cladding was observed.

The only microstructural features observed during the examination that had not been previously identified and reported were a few microcrack-like defects ( $\sim 50 \mu \mathrm{m}$ deep) on the internal surface of one fuel rod from Bundle 0074. These defects are believed to have been formed during fabrication of the cladding; however, they could possibly be shallow SCCs produced during irradiation. The cladding fabrication technology that existed at the time the fuel rods were manufactured produced defects on the internal cladding surface. $(57,58)$ The defects are somewhat similar in appearance to microcracks that form by iodine $\operatorname{scC},(59,60)$ which suggests that they may have been formed by this mechanism. 
Al though the microcracks could have formed during reactor exposure, the necessary conditions for SCC were not available during pool storage. The stress level for the internal surface of the fuel rod during storage was estimated to be insignificant compared with the stresses required to form ${ }^{(61)}$ or propagate ${ }^{(62)}$ iodine SCC in Zircaloy. Therefore, it is not likely that the microcracks will form or propagate during water storage because of the minimal stresses at internal surfaces and the low temperatures that restrict fission product mobility and crack propagation.

The fact that no significant cladding degradation occurred after nearly 21 years of pool storage indicates that successful storage of Zircaloy-clad fuel in water for several decades is an excellent prospect. This conclusion agrees with results from spent fuel examinations in Canada, the Federal Repub1 ic of Germany, and the United Kingdom. The survival of Shippingport fue1, which remained in water in the reactor from 1957 to 1974 (12.3 years at reactor operating conditions; 41,000 MWd/MTU burnup), $(63,64)$ is another impressive demonstration that Zircaloy-clad fuel has excellent resistance to degradation by water.

While at $B C L$, the fuel rods and fuel bundle were stored dry in protective boxes with only normal handling by remote manipulators (sliding, turning, and sectioning of individual rods). No abnormal handling occurred during storage, examination, or sectioning except as noted on pages A.3 and A.4 in PNL-3921. (54) At the conclusion of the hot cell work, the 11 remaining fuel rods from Bundle 0551 and the remainder of Bundle 0074 (116 fuel rods) were readied for dry shipment to the Receiving Basin for off-Site Fuel (RBOF) facil$i$ ty at the Savannah River Plant (SRP). The RBOF facility is a deionized water pool used principally to store spent fuel from university research reactors. As part of the preparations for shipping and subsequent storage, SS identification tags were affixed to the fuel with SS wire. The tags attached to the 3-rod, 3-rod, and 5-rod arrays from Bundle 0551 were stamped "Bundle 0551-1," "Bundle 0551-2," and "Bundle 0551-3," respectively. The tag attached to Bundle 0074 was stamped "Bundle 0074." The fuel was placed in a canister in the BMI-1 cask, and the cask was shipped to the RBOF facility on September 14, 1981. The atmosphere in the cask and canister was moist air. The cask arrived 
at the RBOF facility on September 15, 1981. The cask temperature, as measured through the cask lid upon arrival, was $23^{\circ} \mathrm{C}$. The fuel was unloaded and placed in bucket storage (row: phi; position: CW) in the main storage basin on September 16, 1981. During FY 1982, PNL requested (through DOE-RL) photographs of the stored fuel and information on the storage conditions and received that material from DOE-SR.

On July 22, 1982, RBOF personnel photographed the location (Figures 2 and 3 ) and storage configuration (Figures 4 through 6) of Bundles 0551 and 0074. The fuel location was determined from the RBOF facility material storage log. RBOF personnel then moved the storage basket from that location in the storage basin to a facility working basin and positively identified the Shippingport fuel. After examination, the fuel was moved back to its previous location in the storage basin.

The basin water chemistry is maintained as follows:

Conductivity

Basin water beta-gamma activity

$\mathrm{pH}$
$<3$ m mho/cm

1 to $2 \times 10^{-4}$ microcuries $/ \mathrm{ml}$

5.0 to 9.0

More details of the water chemistry are reported in the Works Technical Report, which is issued monthly by the DOE Savannah River Operations office.

These Shippingport fuel rods will be available for periodic surveillance and examinations in the future, if warranted. Details of such examinations have not yet been determined, but the extensive data base for these rods combined with their existing pool storage histories makes them attractive candidates for future examinations to further define the effects of extended pool storage on fuel rod integrity. Information on the storage conditions will be periodically updated.

\subsection{CONNECTICUT YANKEE FUEL ASSEMBLY SO04}

A Connecticut Yankee (a) qualification fuel assembly, S004, was metallurgically examined by PNL during 1980 and 1981 (Figures 7, 8, and 9). Assembly

(a) The Haddam Neck PWR is commonly referred to as the Connecticut Yankee reactor. 


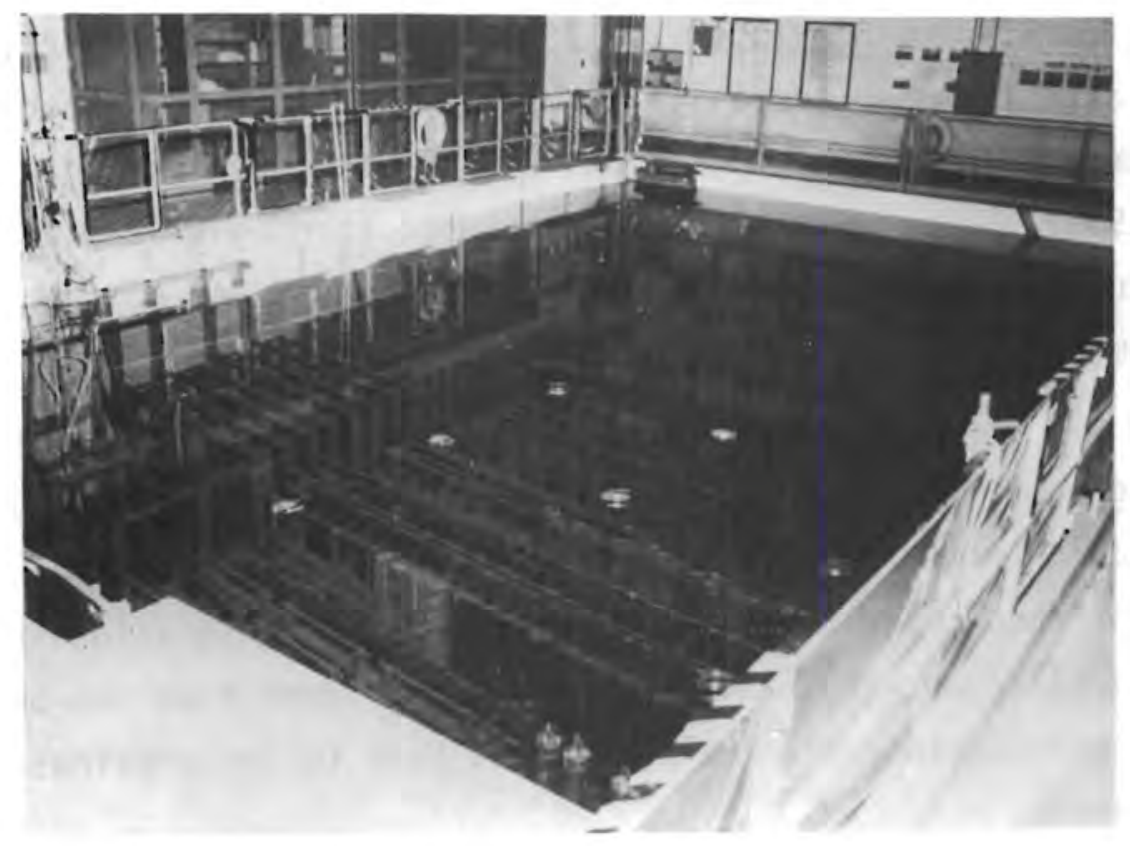

PNL Neg. 83E127-7; SRP Neg. 34420-2

FIGURE 2. RBOF Storage Basin. The Shippingport fuel is located in the far corner (top of picture) $\sim 8.3 \mathrm{~m}(27 \mathrm{ft}$ ) below the water surface.

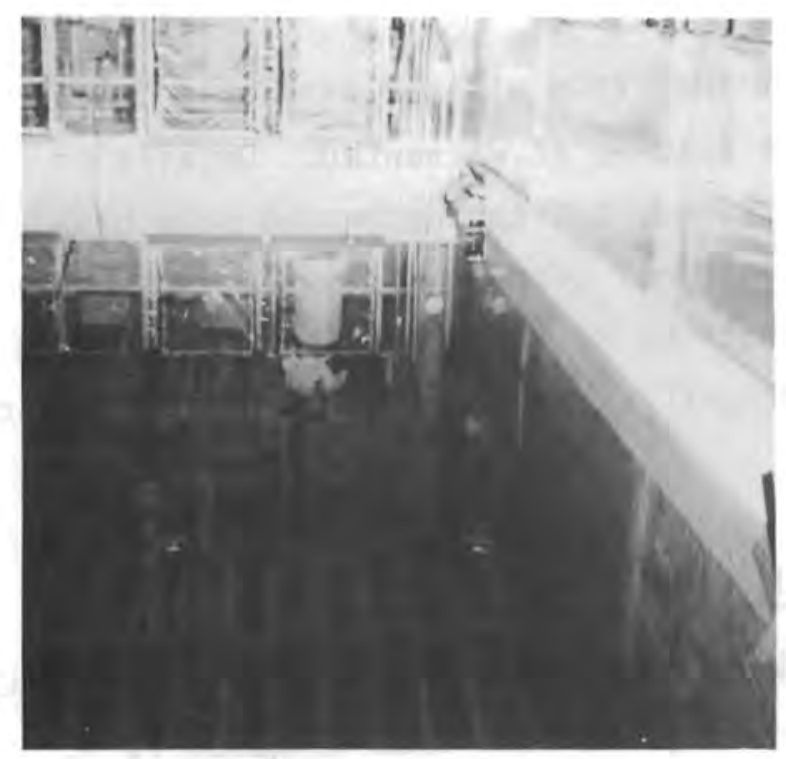

PNL Neg. 83E127-6; SRP Neg. 34420-4

FIGURE 3. Location of Shippingport Fuel in RBOF Storage Basin 


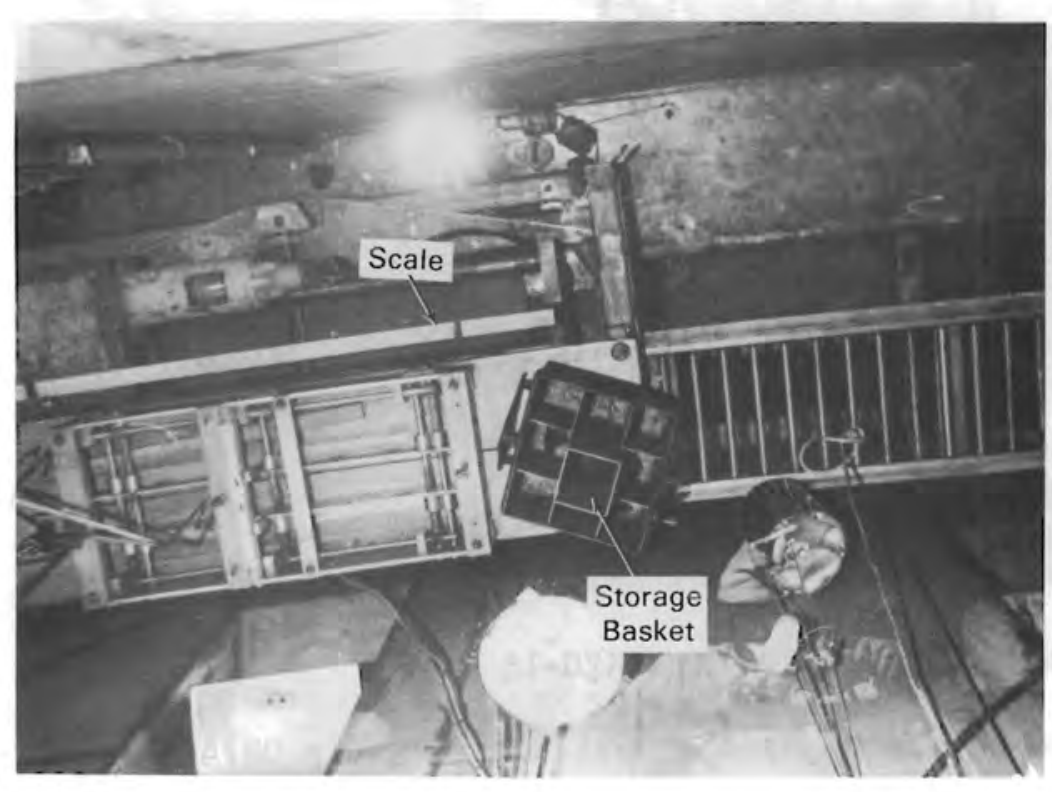

PNL Neg. 83E127-4; SRP Neg. 34420-6

FIGURE 4. Shippingport Fuel in Storage Basket in RBOF "Repack Basin"; 5.2-m (17-ft) Level. The scale in the picture is in inches.

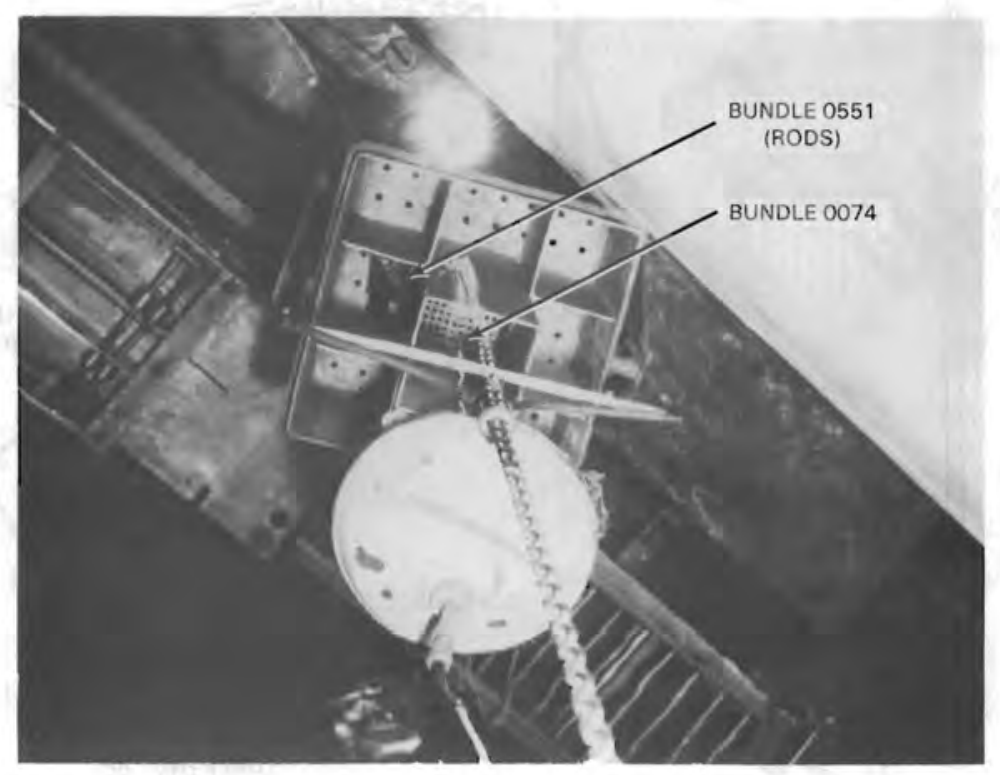

PNL Neg. 83E127-1; SRP Neg. 34420-7

FIGURE 5. Shippingport Fuel at a Raised Level ( $3 \mathrm{~m}$ ) in the "Repack Basin." Groups of fuel rods from Bundles 0551 and 0074 were identified. 


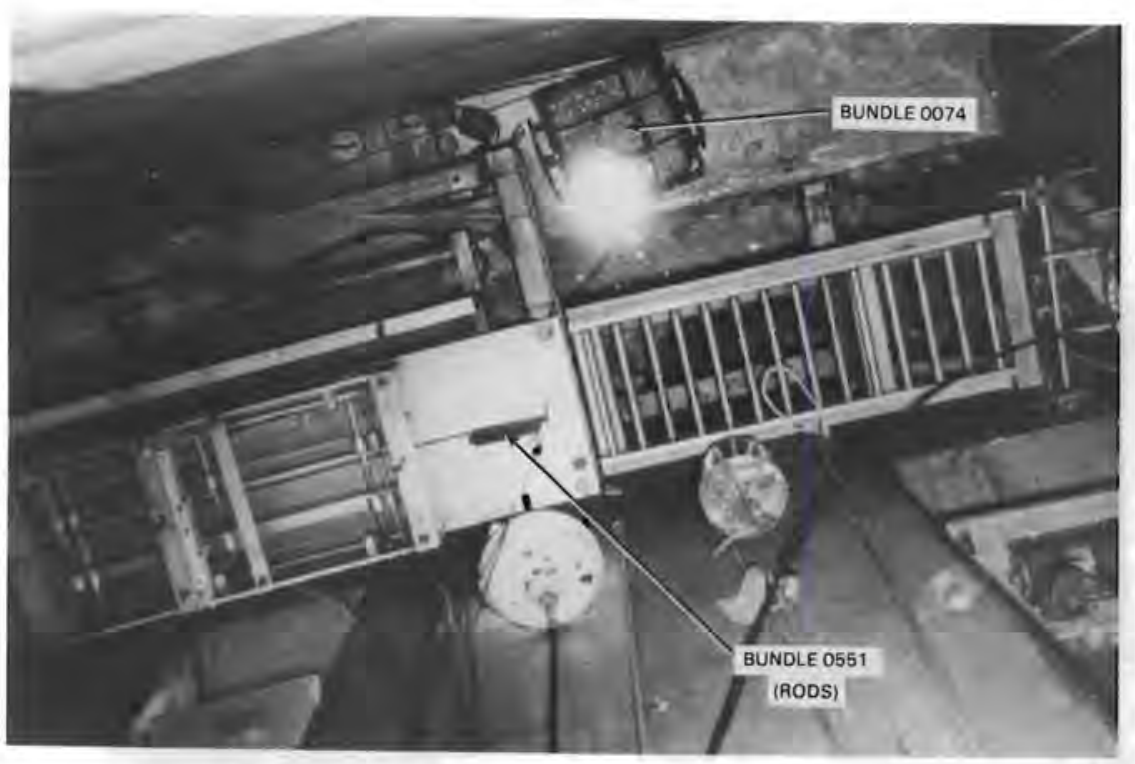

PNL Neg. 83E127-2; SRP Neg. 34420-15

FIGURE 6. Examination of Bundle 0551 Rods (Bundle 0074 in storage basket)

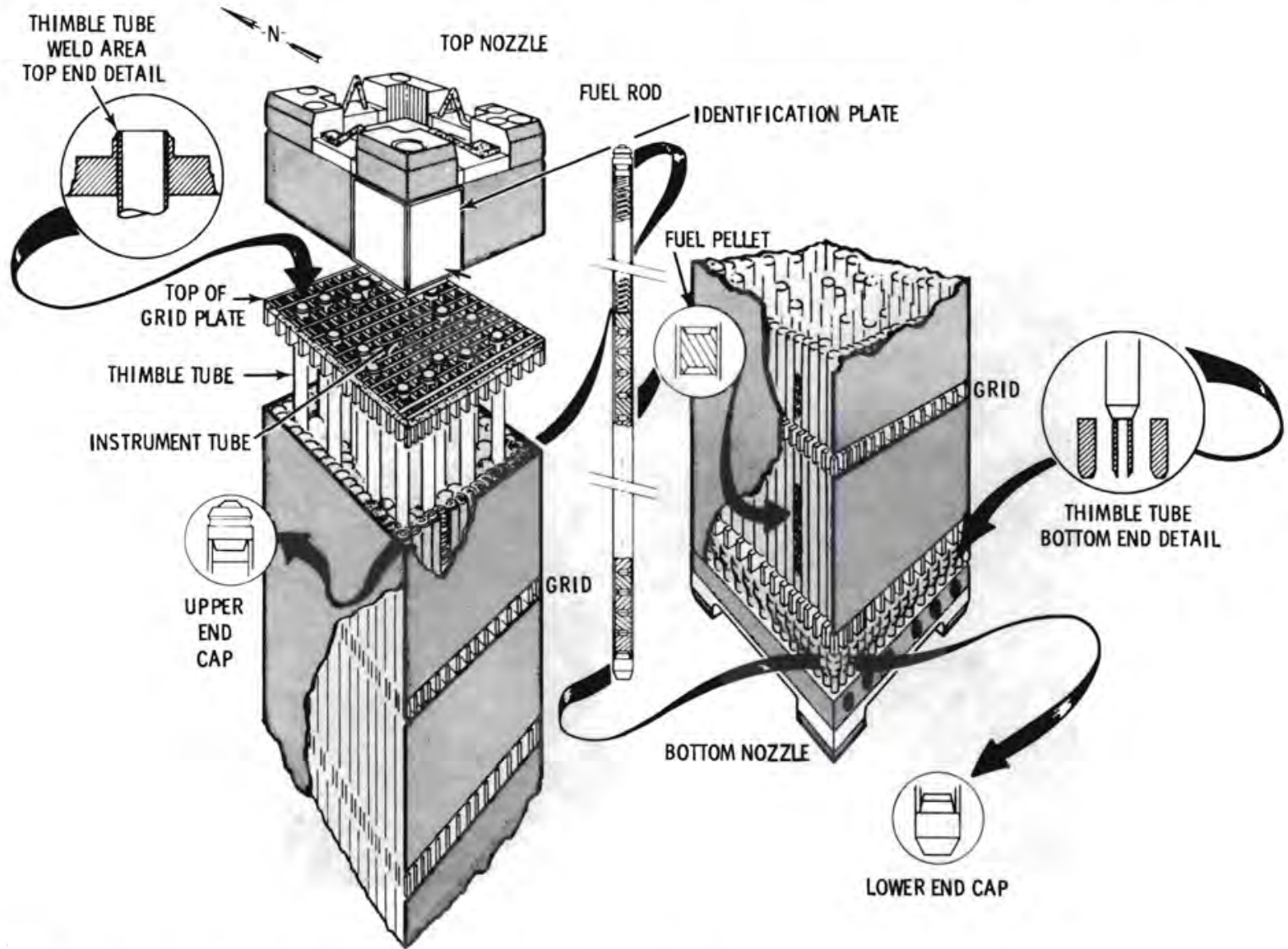

FIGURE 7. Schematic of Connecticut Yankee Qualification Fuel Assembly S004, Including Details of the Thimble Tube Weld Areas 

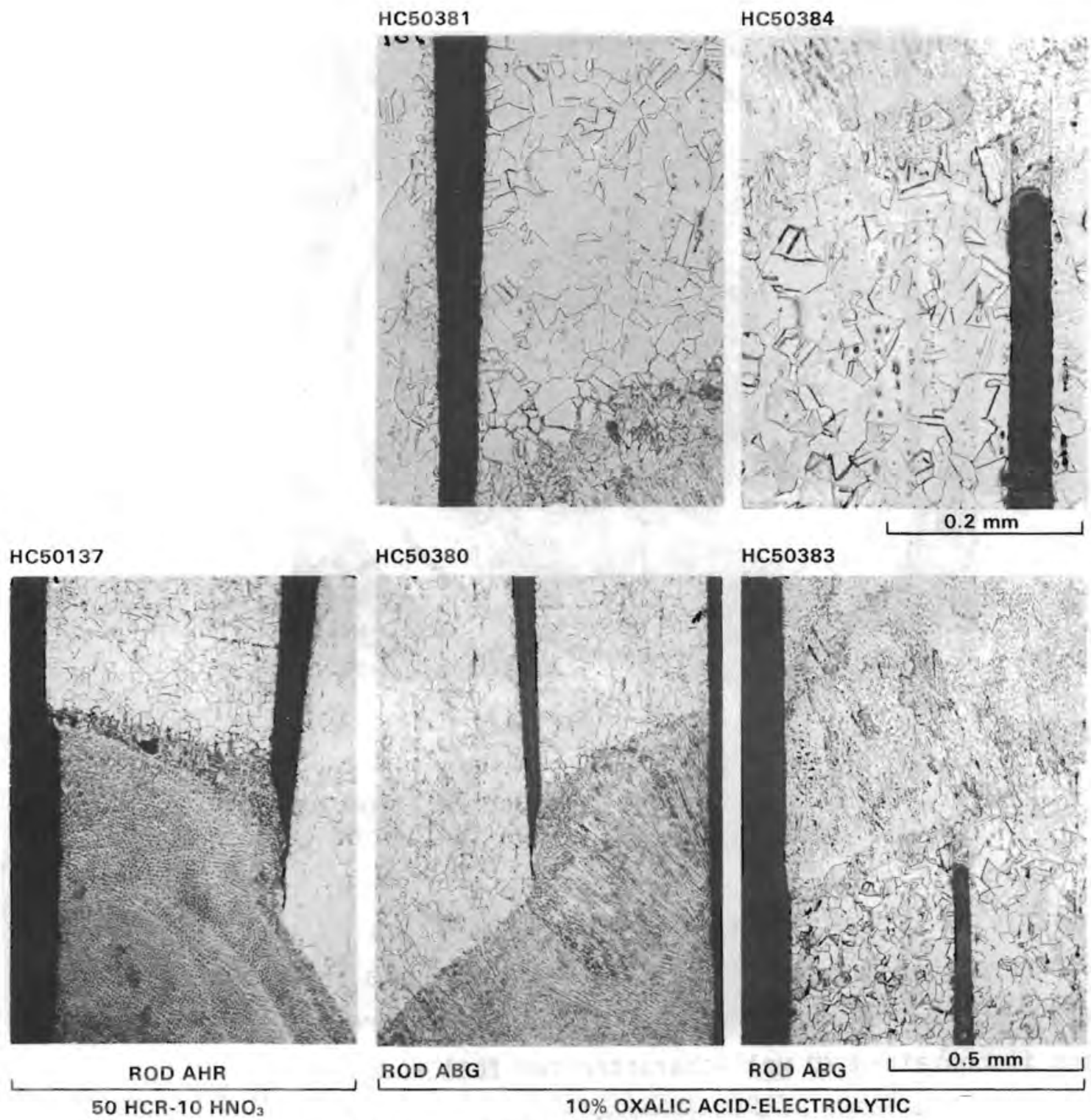

HC50380

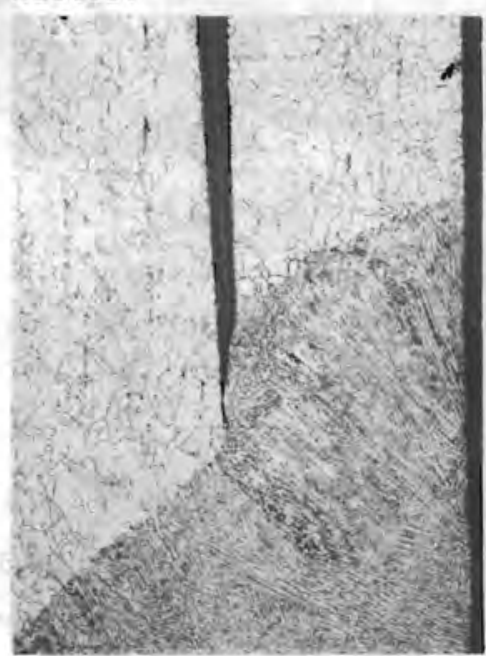

ROD ABG
HC50383

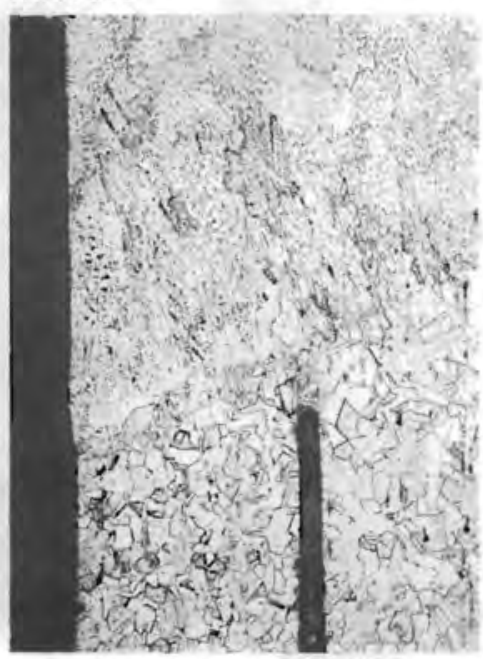

ROD ABG

10\% OXALIC ACID-ELECTROLYTIC

FUEL ROD END CAP WELD AREAS

FIGURE 8. Metallography Showing the Heat-Affected Zone of End Cap Weld Areas from Connecticut Yankee Assembly S004 Fuel Rods (1ongitudinal section; etched condition) 


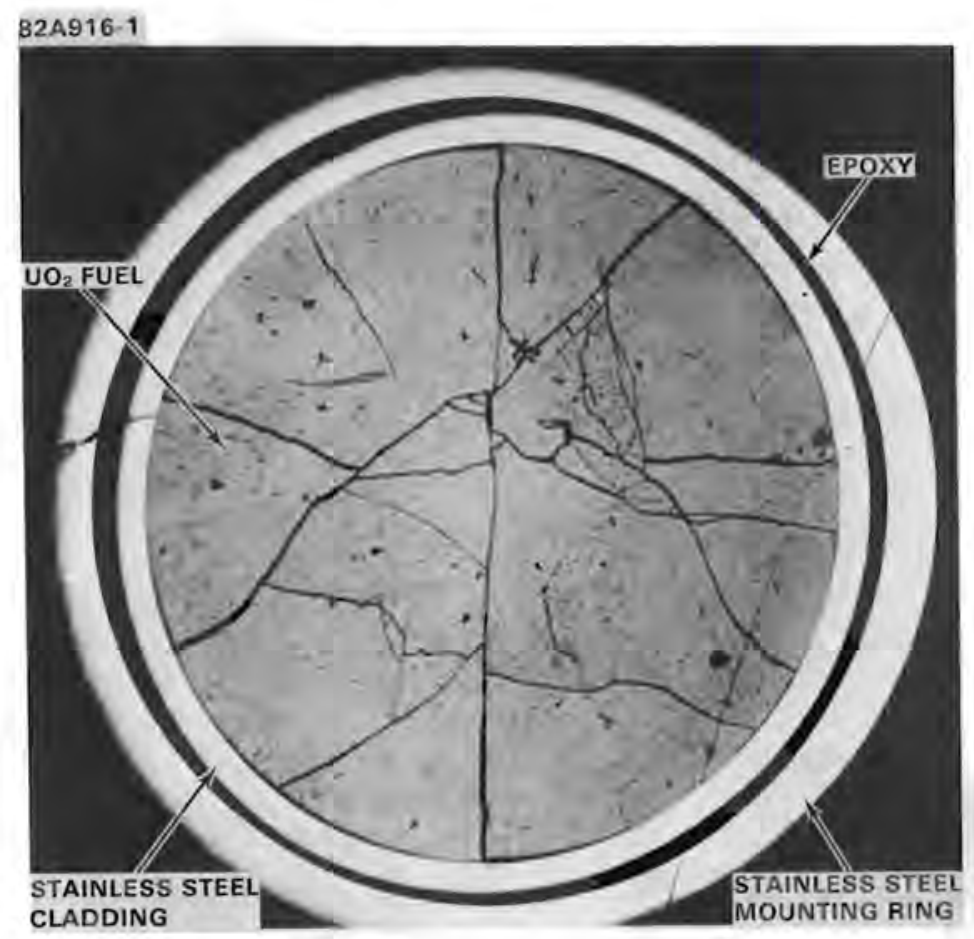

Neg. 82A916-1

FIGURE 9. As-Polished Surface from Rod AHR from Assembly S004 at $56.75 \mathrm{in}$. $(144 \mathrm{~cm})$ Above the Bottom of the Rod

S004 is a SS-clad assembly that was selected by PNL for examination because it had no known reactor-induced defects, it had attained a relatively high burnup (the average burnup was $32.2 \mathrm{MWd} / \mathrm{kgU}$ ), it had been stored 5 years in borated water, and it contained 20 we11-characterized fuel rods.

Of the spent fuel stored in the United States, most ( 95\%) has Zircaloy cladding; the remainder $(\sim 5 \%)$ has SS cladding. Stainless steels are susceptible to SCC in a variety of environments. A few SS pipes at domestic PWR spent fuel pools have developed IGSCC at weld heat-affected zones (HAZs). (65) As noted earlier (Section 4), the top end fitting (nozzle) separated from the remainder of a spent fuel assembly at Prairie Island-1 (PWR) as it was being pulled out of a storage rack at a spent fuel pool. $(66,67)$ IGSCC was the apparent cause of the failure of the SS components in that fuel assembly. (68) Such considerations suggest that SS-clad water reactor fuel could be more susceptible to stress-related corrosion than Zircaloy-clad fuel. The general lack of data led PNL to initiate a study of the corrosion of SS-clad fuel during water storage. 
Results of the S004 examination have been published in PNL-3828(69) and elsewhere $(1,2,55,56)$ and are summarized below. While assembly S004 was being examined, two other Connecticut Yankee fuel assemblies (HO7 and G11) were being examined at the BCL facility for the Northwest Utilities Service Company (NUSCO) and the Electric Power Research Institute (EPRI). These assemblies also contained SS-clad fuel rods. Assembly $\mathrm{H} 07$ contained some failed fuel rods and had an average burnup of $35.8 \mathrm{MWd} / \mathrm{kgU}$. There were no failed fuel rods in assembly G11, which had an average burnup of $36.7 \mathrm{MWd} / \mathrm{kgU}$. Results of the NUSCO/EPRI study have been published.(70) The principal aim of the NUSCO/EPRI investigation was to determine the cause of the cladding failures that occurred in assembly H07 during reactor residence. However, NUSCO and EPRI agreed to provide PNL with any evidence regarding the presence or absence of p001-induced effects. NUSCO/EPRI and PNL also agreed to interchange a few rods from the three assemblies when they are reconstituted before shipment from the hot cell for subsequent extended storage.

The examination of assembly S004 revealed that no obvious degradation of the Type 304L SS-clad fuel rods had occurred after 5 years ${ }^{(a)}$ of storage in borated water. The corrosion and deposits of corrosion products (crud) on the fuel rods from assembly S004 were very similar to those observed on the Type 304 SS-clad fuel rods from assemblies $\mathrm{H} 07$ and G11, which had been stored for shorter periods (1.3 and 2.6 years, respectively). The fuel rods from assemblies S004, H07, and G11 were relatively free of crud and oxide films. Pellet chips were lodged in the fuel-cladding gaps of fuel rods from assemblies $\mathrm{H} 07$ and G11, but not in those from assembly S004. Pellet chips in fuel rods from assembly S004 were also much smaller than those found in fuel rods from assemblies $H 07$ and G1l. No cladding breaches, with concomitant loss of fission products and/or fuel, or ingress of coolant occurred in the precharacterized fuel rods of assembly S004 that were inspected during the postirradiation examination. These conclusions were based on: reactor operating data, leak test (sipping) results, rod weight measurements, and eddy-current test results. The cladding and weld metallography was very similar for the fuel rods that were examined from assemblies S0O4, H07, and G11.

(a) Degradation of SS pipes at PWR spent fuel pools (borated water) has occurred in less than 5 years. 
The metallographic examination of the cladding from assembly S004 fuel rods showed no evidence of cracks, pitting, or significant general corrosion on either the outer surface or inner surface of the cladding. Cracks, pitting, or significant general corrosion were also not evident in cladding seam weld or end cap weld areas on fuel rods from assemblies S0O4, H07, and G11. A qualitative indication of good ductility was evident from the results of the ring crush tests of irradiated cladding from fuel rod AHR of assembly SO04. Irradiation strengthening, with a concomitant reduction of ductility, was observed in the cladding from fuel rod AHR of assembly S004, assuming the unirradiated strength and ductility were similar to those of the Type 304 SS archive cladding used on fuel rods in assembly $\mathrm{H} 07$. The test results indicate that the mechanical properties of the irradiated cladding are deformation rate dependent. There are at least two operating temperature regimes (i.e., some fuel rods operated with higher centerline fuel temperatures than others) represented in the fuel rods from assembly S004, based on fission gas release (order of magnitude difference noted) and fuel microstructural information from the fuel rods that were destructively examined.

Assembly S004 was shipped from the reactor site in an air-filled cask, arrived at the BCL hot cell facility on May 14, 1980, and was placed in the BCL pool (deionized water) on May 16, 1980. Except for the times it was moved from the pool to the hot cell during the period of examination (May 1980 to September 1981), the assembly remained in the pool (specifically, in Storage Hole No. 6). Through November 1980, the pool water temperature was 20 to $25^{\circ} \mathrm{C}$ and the conductivity was 0.77 to 1.25 umho/cm. From December 1980 through May 1983, the temperature was 28 to $29^{\circ} \mathrm{C}$. Between November 1980 and September 1981, the conductivity typically ranged between 0.64 and 2.44 umho/cm, except for a short period (1ess than 14 days) in March-April 1981 when the value reached 37.7 umho/cm. Pool water samples are collected and analyzed weekly for radioactivity (gross beta-gamma), which tends to be on the order of $10^{-4}$ microcuries/ml. The pool has no heat exchanger. The water is continuously purified through an ion-exchange resin column system; and deionized water is added, when needed, to maintain the specified level. BCL indicated on September 29, 1983, 
that the pool water analysis showed: $\mathrm{F}^{-}$, not detected; $\mathrm{C}^{-}, 0.0036 \%$; and $\mathrm{SO}_{4}^{2}$, $0.0025 \%$. It is planned to periodically update the data on the storage conditions of assembly 5004 and the associated fuel rods that are separately stored.

Two fuel rods (ADT and AGD) that were drilled for fission gas collection have remained in the hot cell (i.e., in dry storage). For the period up through May 1983, the temperature in the hot cell was 23 to $25^{\circ} \mathrm{C}$. If sealed, the rods could be reinserted into assembly 5004 , which would eliminate the rod storage charges. $B C L$ could seal such holes by welding; however, the technique was developed for and has only been used by BCL on Zircaloy-clad fuel. BCL believes the technique could be adapted for use on the SS-clad fuel.

Contractual arrangements between PNL and BCL were completed early in September 1981 for the reconstitution of assembly S004.(a) Mutual agreement was reached earlier with NUSCO/EPRI on the interchange of five fuel rods (AEK, AEI, ADU, ALF, and AJQ) from assembly S004 for one fuel rod (595A01) from assembly G11 and four fuel rods (065E11, 1007E01, 010E03, and 075E05) from assembly H07. When rod $010 \mathrm{E} 03$ from assembly $\mathrm{H} 07$ was later found to have been unintentionaliy cut, it was replaced with rod 595A11 from assembly G11. The nondestructive tests performed on those fuel rods are summarized in Tables 3 and 4.

Reconstitution of assembly S004 began in September 1981 but remains to be completed. After some fuel rods had been inserted, further work was stopped for safety reasons (the cable on the transfer device, which is used to manipulate the fuel assembly, needed to be repaired). The transfer device was subsequently modified. The rod transfers completed to date in assembly s004 are shown in Figure 10, and the planned final loading of assembly S004 is shown in Figure 11. The top nozzle is currently detached from the assembly. Work on reattaching the top nozzle was halted by PNL when the Prairie Island-1 broken nozzle incident (see Section 4.1) occurred, in case additional examination of the assembly s004 nozzle might be warranted. It is planned to reattach the top nozzle to assembly S004 with bolts that extend through both the top and bottom

(a) Involved reinsertion of the nondestructively examined fuel rods from assembly 5004, insertion of one fuel rod from assembly G11 and four fuel rods from assembly $\mathrm{H} 07$, and reattachment of the top nozzle from assembly 5004 . 
TABLE 3. Summary of Characterizations on Fuel Rods From Assembly 5004

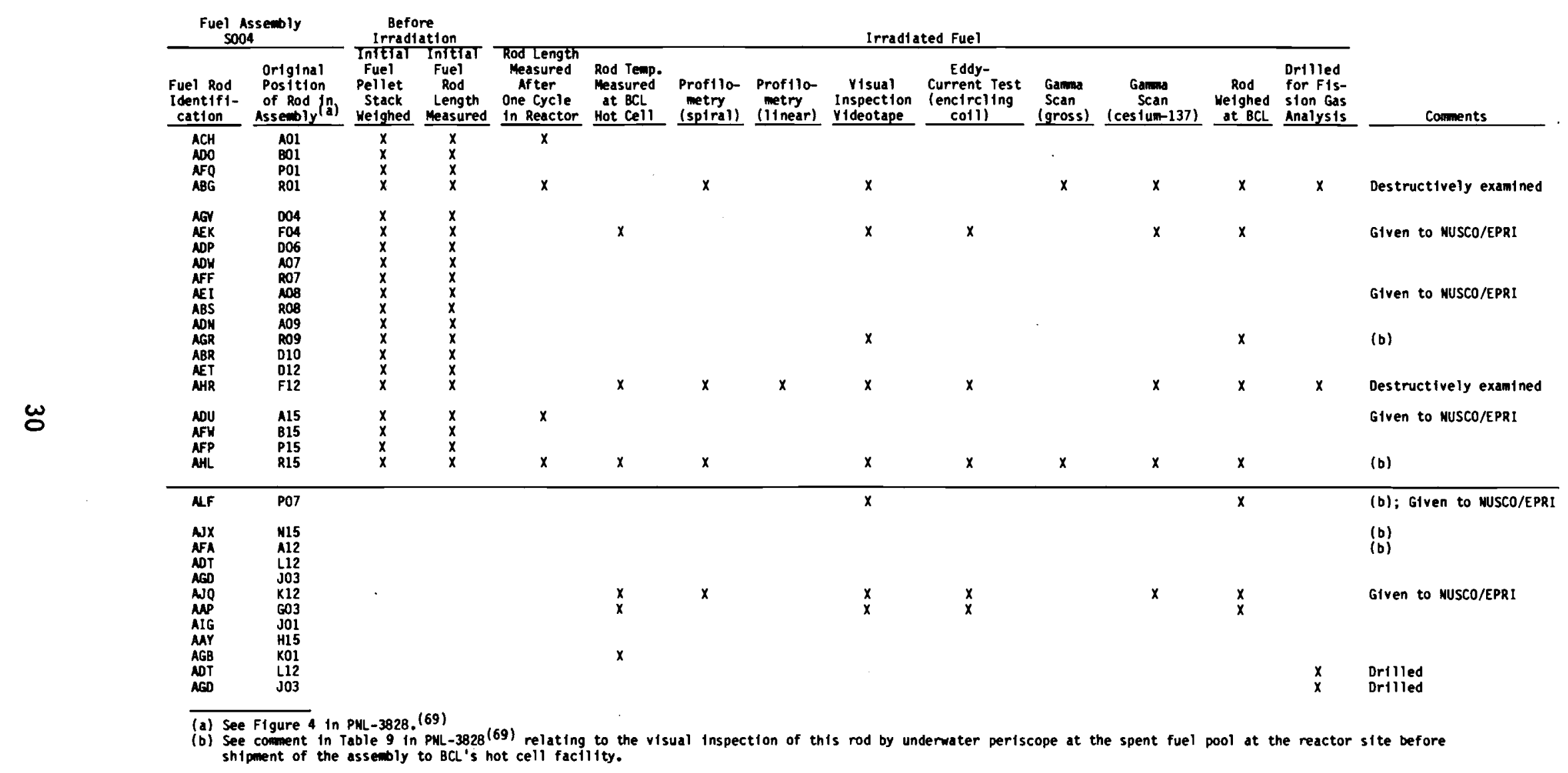




\section{TABLE 4. Five Unfailed Fuel Rods from Assemblies G11 and H07 to be Inserted in Assembly SO04}

\begin{tabular}{|c|c|c|c|c|c|c|c|c|c|}
\hline \multirow[b]{2}{*}{$\begin{array}{l}\begin{array}{l}\text { Fuel Assembly } \\
\text { Identification }\end{array} \\
\end{array}$} & \multirow[b]{2}{*}{$\begin{array}{c}\text { Fuel Rod } \\
\text { Identification }\end{array}$} & \multirow[b]{2}{*}{$\begin{array}{l}\text { Original Pos- } \\
\text { tion of Rod in } \\
\text { Assembly } \\
\text { As) }\end{array}$} & \multirow[b]{2}{*}{$\begin{array}{c}\text { Profilometry } \\
\text { (Spiral) }\end{array}$} & \multirow[b]{2}{*}{$\begin{array}{l}\text { Profilometry } \\
(\text { Linear) }\end{array}$} & \multicolumn{2}{|c|}{ Eddy-Current Test } & \multirow[b]{2}{*}{$\begin{array}{r}\text { Gamma } \\
\text { Scan } \\
\text { (Gross) } \\
\end{array}$} & \multirow[b]{2}{*}{$\begin{array}{c}\text { Gamma } \\
\text { Scan } \\
\text { (Cesium-137) } \\
\end{array}$} & \multirow[b]{2}{*}{ Comments } \\
\hline & & & & & $\begin{array}{c}\text { Encircling } \\
\text { Coil } \\
\end{array}$ & $\begin{array}{l}\text { Probe } \\
\text { Coil } \\
\end{array}$ & & & \\
\hline \multirow[t]{4}{*}{ H07 } & 065E11 & G04 & $x$ & 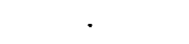 & & & & & \\
\hline & $010 E 03$ & L12 & $x$ & & $x$ & $x$ & & & $\begin{array}{l}\text { Cut in error by } \mathrm{BCL} \\
\text { and replaced }\end{array}$ \\
\hline & 075E05 & $\mathrm{k} 12$ & $x$ & & $x$ & & & & \\
\hline & $1007 E 1$ & E04 & $x$ & & $x$ & & & & Slightly damaged $(c)$ \\
\hline \multirow[t]{2}{*}{ G11 } & 595A01 & R11 & & & & & $x$ & $x$ & \\
\hline & 595A11 & G11 & & & & & & & $\begin{array}{l}\text { Replacement for rod } 010003 \\
\text { from assembly } \mathrm{HO} 7\end{array}$ \\
\hline
\end{tabular}

(a) See Figure 2 in EPRI NP-2119. (70)

(b) Three of eleven unfailed rods (includes the six listed) were also profiled in a nonrotating mode to obtain linear scans.

(c) BCL indicated in September 1982 that this rod was slightly damaged (s) ight bend in the plenum area). BCL leak checked and photographed the rod; PNL agreed to use of the leak-free rod. 


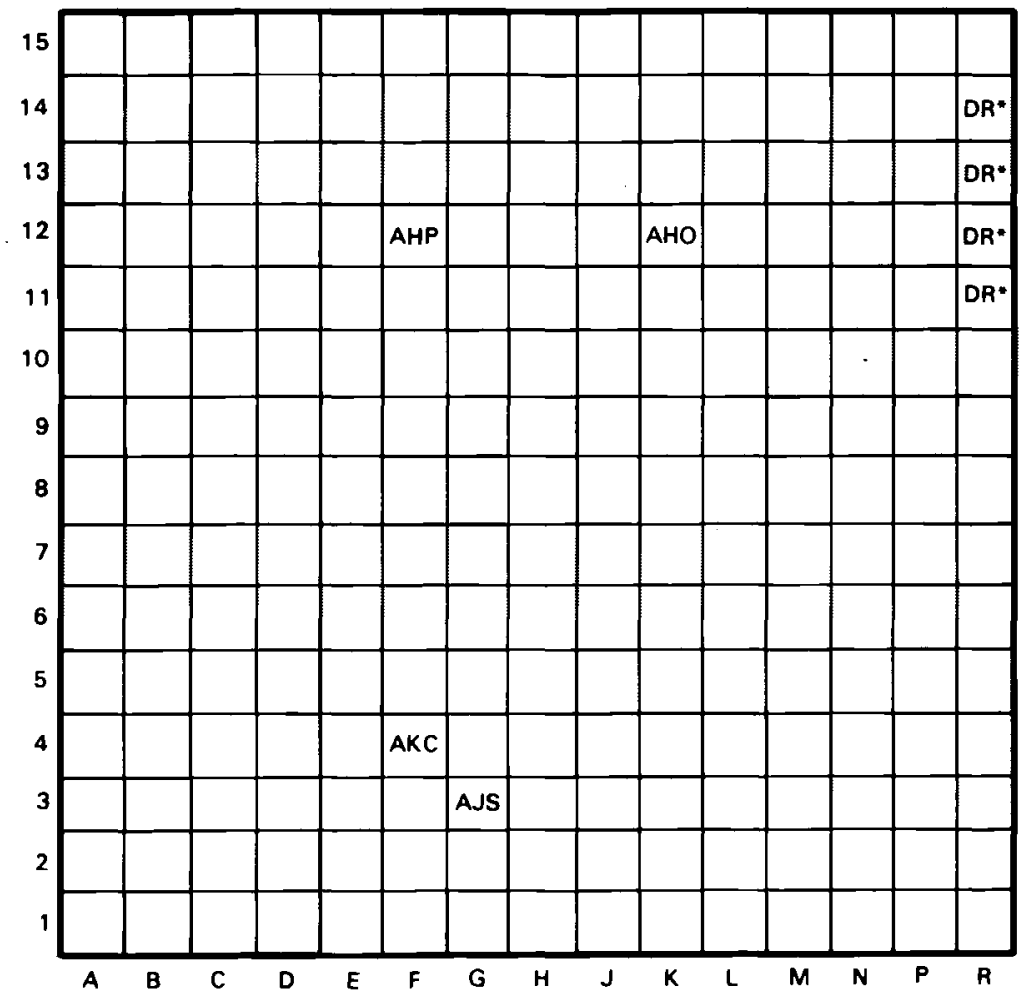

FIGURE 10. Rod Transfers That Have Been Made in Assembly SOO4 (*A SS dummy rod (DR) was temporarily inserted in this position.)

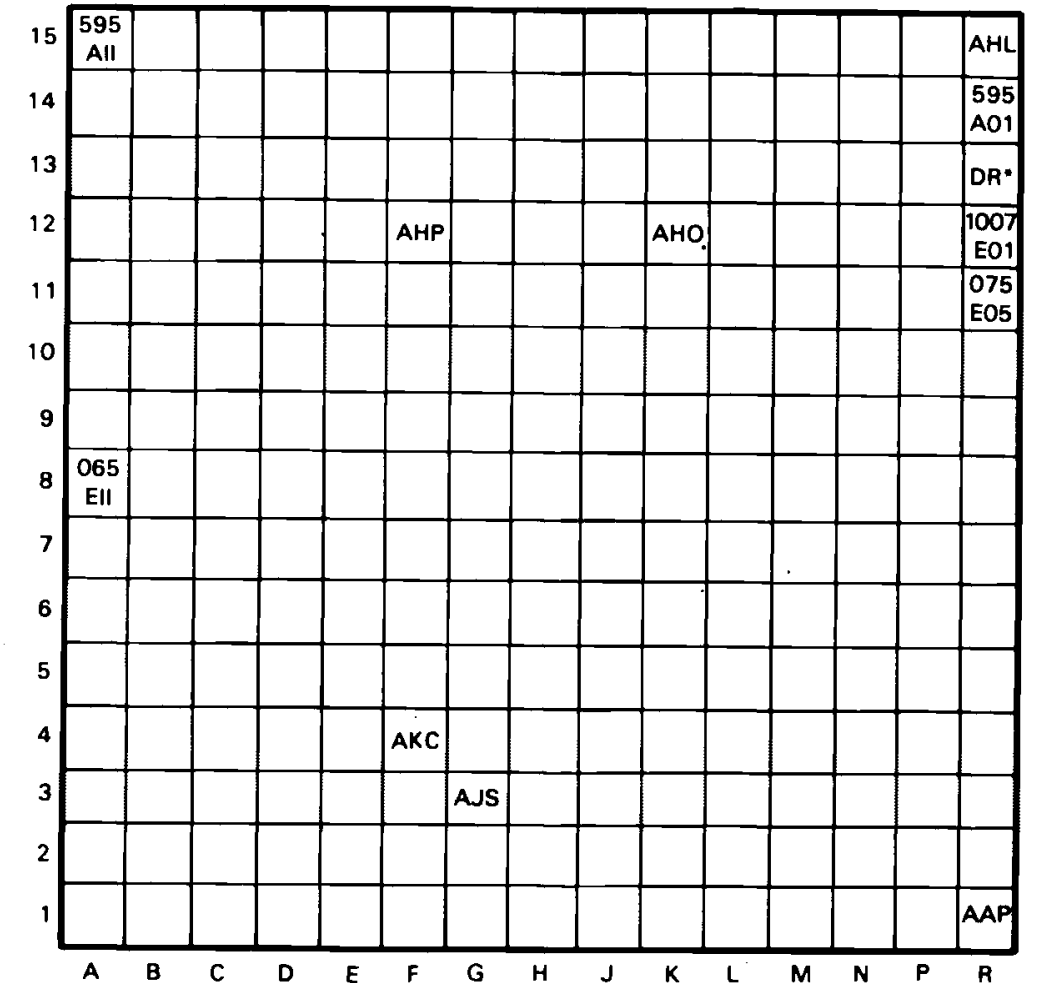

FIGURE 11. Planned Final Loading of Rods in Assembly SO04 (*A SS dummy rod (DR) is to remain in this position.) 
nozzles. To provide supplemental support (particularly, to make the reconstituted assembly less prone to bending), special expansion bolts, which are sized to fit into the control rod guide tubes, were fabricated by PNL and five were shipped to BCL. The short SS expansion bolts are of the type designed and previously used by British Nuclear Fuels Limited (BNFL) on irradiated fuel assemblies in cases where the top nozzles had been cut off and the nozzles needed to be reattached to facilitate handling of the fuel assemblies. These special expansion bolts are inserted through the top nozzle and into the cut ends of the guide tubes that are still attached to the bottom nozzle. When the nuts on the special bolts are tightened, the portions of the bolts in the guide tubes expand and mechanically grip the tubes.

\subsection{INSPECTION OF FAILED OCONEE FUEL}

PNL contracted with Babcock and Wilcox Company (B\&W) to nondestructively examine defective fuel rods in five PWR fuel assemblies (two from Oconee-1 and three from Oconee-2). The Zircaloy-clad fuel was examined in 1982 at a spent fuel pool at the Oconee Nuclear Station, which is operated by Duke Power Company. The fuel rods were not removed from the fuel assemblies for the examination. The five B\&W commercial fuel assemblies (Table 5) had known defects, which had developed during reactor operation, in peripheral fuel rods; and the assemblies had been in wet storage at Oconee since reactor discharge. The two 0conee- 1 assemblies and three 0conee- 2 assemblies had been examined 7 and 4 years earlier, respectively. Results of the recent examination were submitted by B\&W (RDD:83:4054-01:01) to PNL and have been published. (71) The results are summarized below.

Visual examinations, conducted by periscope and closed-circuit television, indicated that neither the defects nor the immediate areas surrounding them changed significantly from what was observed during the examinations that were conducted when the defects were first discovered. Figure 12 shows the large defect in Rod C14 in fuel assembly 1A10. The defect is $\sim 10 \mathrm{~cm}$ (4 in.) below the fourth splacer grid from the top of the assembly. 

TABLE 5. Oconee Fuel Assemblies yith Defective Fuel Rods
Examined by B\&W for PNL

Fuel Assembly Identification $1 \mathrm{~A} 1 \mathrm{O}^{(\mathrm{b})}$ $1 A 19$ (b) $2 \mathrm{~B} 22(\mathrm{c})$ $2 \mathrm{~B} 25(\mathrm{C})$ $2 \mathrm{~B} 47^{(\mathrm{C})}$

\begin{tabular}{|c|c|}
\hline Reactor & Cycle(s) \\
\hline Oconee-1 & 1 \\
\hline Oconee-1 & 1 \\
\hline Oconee-2 & 1 and 2 \\
\hline Oconee-2 & 1 and 2 \\
\hline Oconee-2 & 1 and 2 \\
\hline
\end{tabular}

\begin{tabular}{|c|c|}
\hline $\begin{array}{c}\text { Discharge } \\
\text { Date }\end{array}$ & $\begin{array}{l}\text { Burnup, } \\
\text { Mwd/kgU }\end{array}$ \\
\hline October 1974 & 12.1 \\
\hline October 1974 & 12.1 \\
\hline June 1974 & 23.1 \\
\hline June 1977 & 24.6 \\
\hline June 1977 & 26.3 \\
\hline
\end{tabular}

(a) Fuel assemblies were examined by B\&W for PNL. The defects were discovered and documented during examinations following discharge. Assemblies $1 \mathrm{~A} 10$ and $1 A 19$ were examined in March and April 1975, respectively; assemblies 2B22, 2B25, and 2B47, in July 1978 .

(b) Based on radioiodine levels in the primary coolant, B\&W estimated that the defects in $1 \mathrm{~A} 10$ and $1 \mathrm{~A} 19$ occurred early in life (during the first $10 \%$ of the cycle).

(c) Based on the large iodine concentration that was present early in Cycle 2, B\&W estimated that the bulk of the defects in Batch 2 fuel (assemblies numbered $2 B X X$ ) occurred at the start of their second cycle, when the assemblies had attained a burnup of $\sim 14 \mathrm{MWd} / \mathrm{kgU}$.

Diameters of both defective rods and presumably inlet rods were measured. Continuous diameter scans were made on two rods (a failed rod and a nearby intact rod) from each of these assemblies: 1A10, 1A19, 2B22, and 2B47. Fuel assembly $2 \mathrm{~B} 25$ was not included because, in contrast with the other four assemblies, its failed rod was not on the periphery. The diameter and ovality results were generally consistent with what would be expected for the particular reactor duty cycles involved, al though there was anomalous cladding strain in two of the rods away from the defects themselves. There was no evidence that pool storage resulted in any cladding strain beyond that produced by in-reactor service.

Seven years earlier, gamma scanning of one of the failed rods (Rod C14 in fuel assembly 1A10) revealed that the fuel was missing in an $8-\mathrm{cm}\left(3-\mathrm{in}_{0}\right)$ long region near the defect. This rod was scanned again during the recent examination (Figure 13), and the defect was essentially no larger than before. 

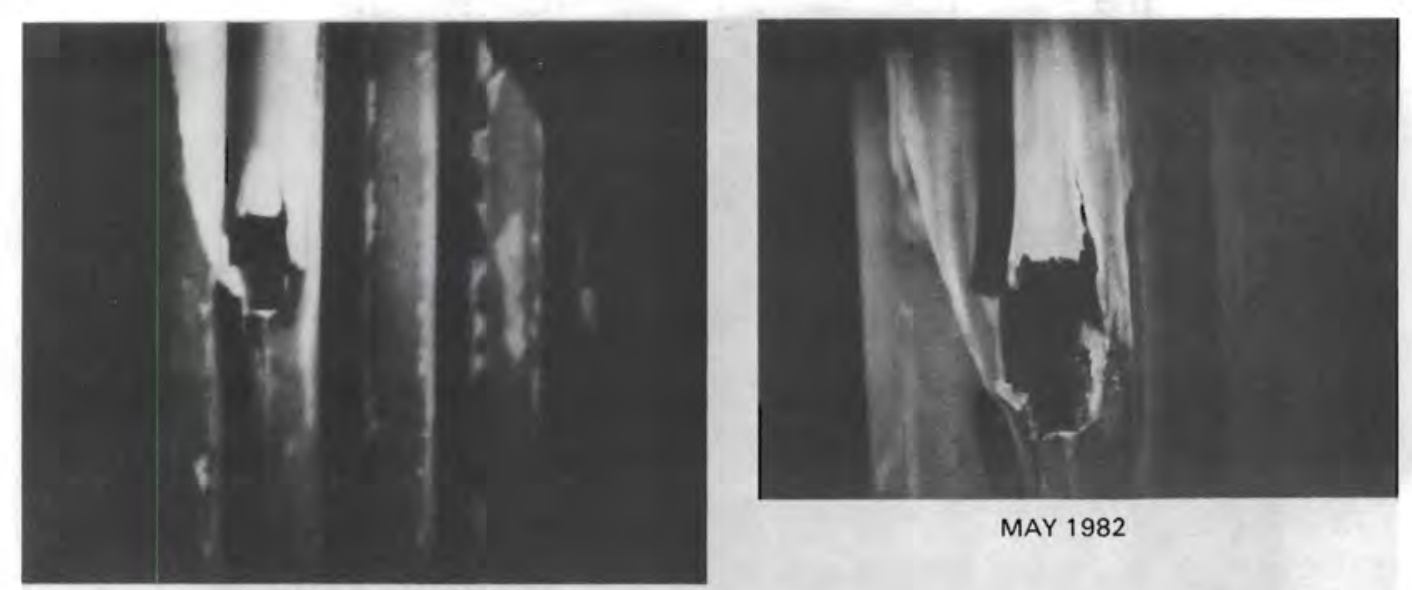

MAY 1982

MARCH 1975

OCONEE-1 FUEL ASSEMBLY

DISCHARGED: OCTOBER 1974

BURNUP: $12,100 \mathrm{MWd} / \mathrm{MTU}$

NOTE: $8 \mathrm{~cm}$ (3 in.) OF FUEL MISSING

PNL Neg. 83G511-2

B\&W Neg. $1 \mathrm{~A} 10(3 / 75), 78-26$

FIGURE 12. Periscope Photographs of Fuel Assembly 1A10 Showing the Large Defect in Rod C14. The as-fabricated rod diameter was $10.9 \mathrm{~mm}(0.430 \mathrm{in.})$. 


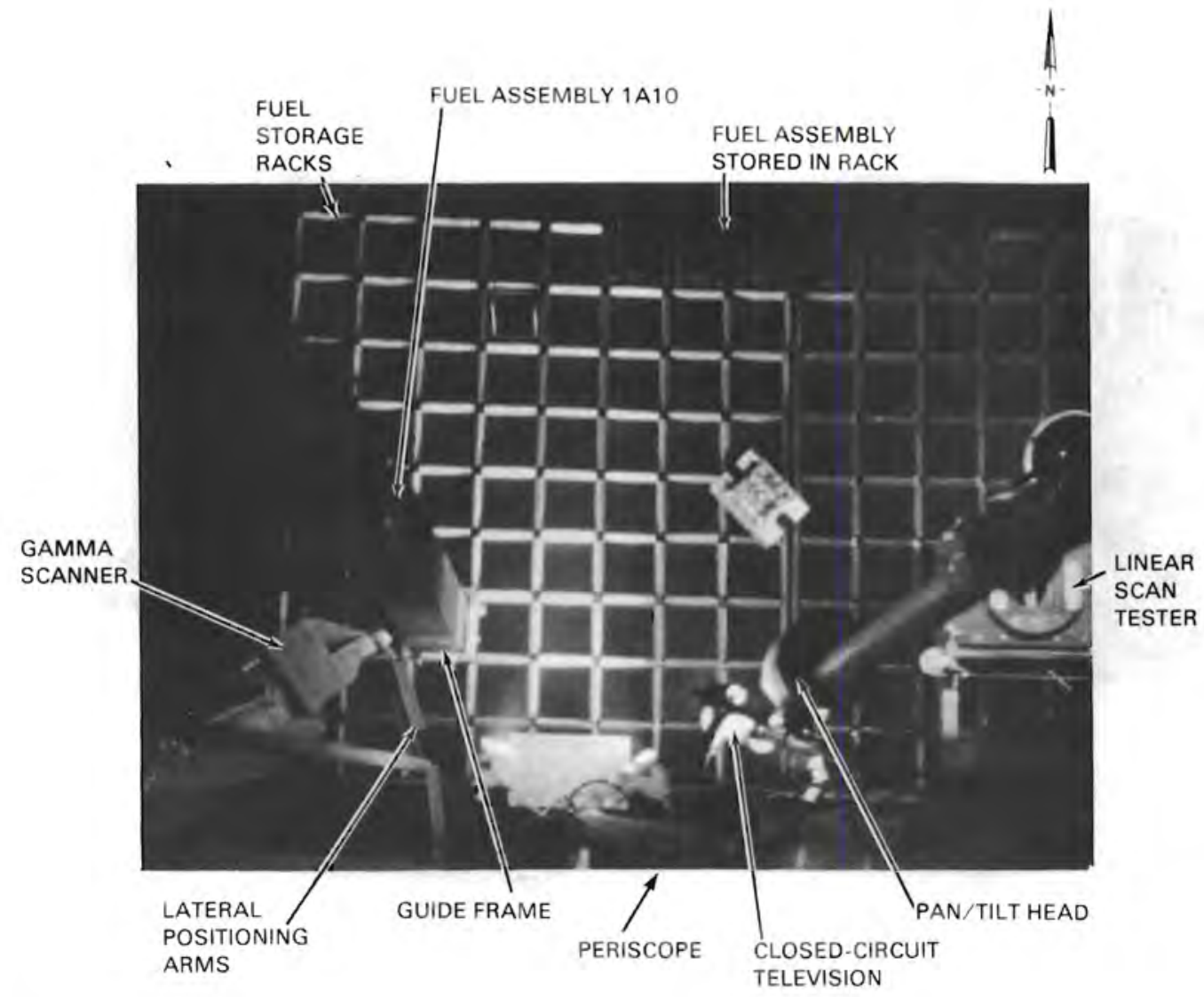

PNL Neg. 83G511-3

B\&W Neg. 78-36

FIGURE 13. Postirradiation Equipment in the Oconee Spent Fuel Pool with Fuel Assembly 1 A10 Being Gamma Scanned 
In comparing the appearance of the fuel assemblies in 1978 and in 1982, $B \& W$ indicated that the crud $^{(a)}$ (corrosion product deposit) had undergone some changes--it appeared rather adherent in 1978 but showed flakiness and a tendency to peel off in 1982 (Figure 14). During the 1982 examinations, a considerable amount of the crud came loose from the five assemblies during the associated handling operations.

$B \& W$ concluded that the examinations showed no significant changes to the integrity of the defective rods that could be attributed to wet storage of the spent fuel.

(a) In contrast to the corrosion layer instrinsic to a given structural material on a spent fuel assembly, the crud deposits on a spent fuel assembly result primarily from mass transfer processes operating on the corrosion/ erosion products from the various structural materials in contact with the primary coolant circuit in the LWR. The crud deposits become radioactive by neutron activation. Crud species on spent LWR fuel assemblies are found in two forms: loose and tenacious. Loose crud is found more frequently on BWR fuel assemblies than on PWR fuel assemblies. 


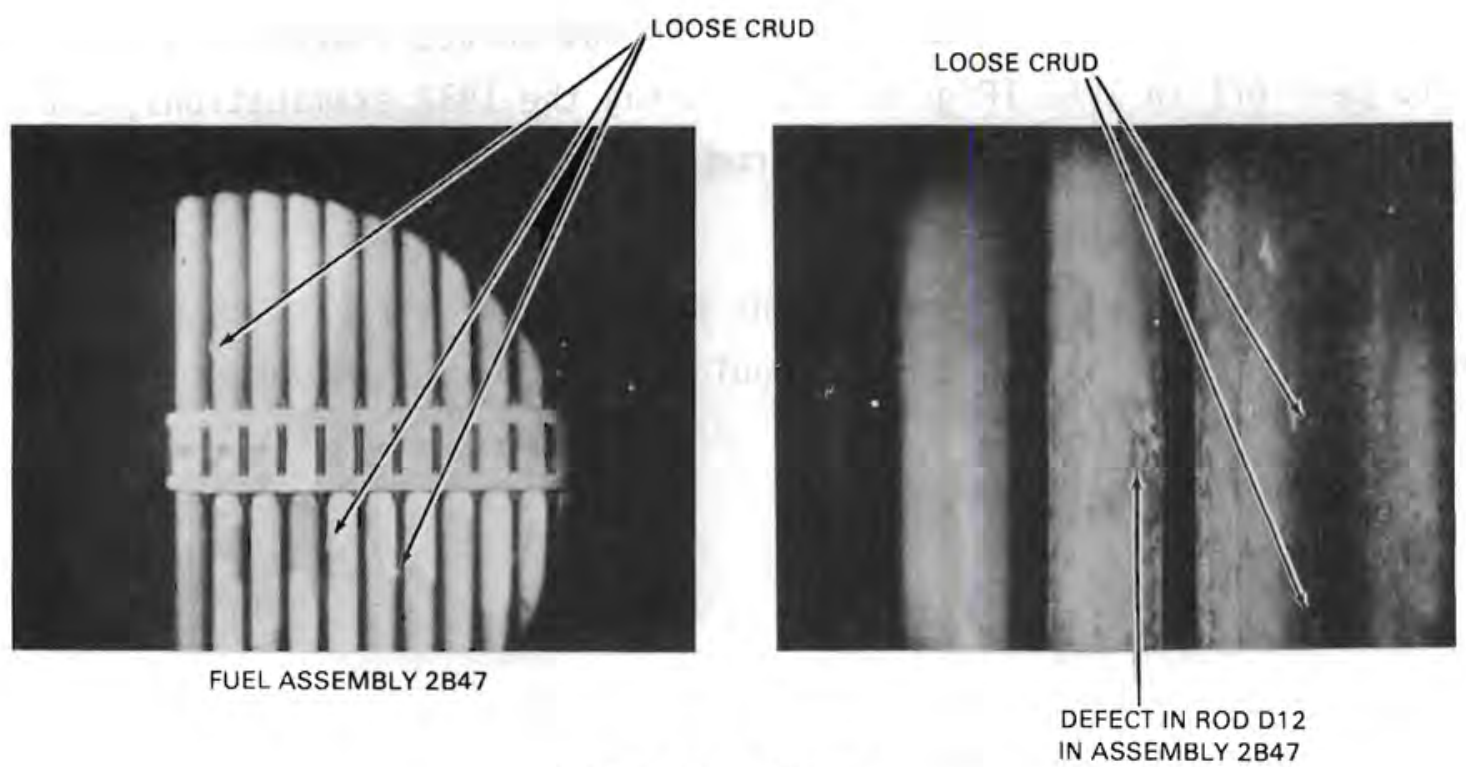

OCONEE-2 FUEL ASSEMBLY

BURNUP: $26,300 \mathrm{MWd} / \mathrm{MTU}$

PNL Neg. 83G511-1

B\&W Neg. 77-23, 78-3

FIGURE 14. 1982 Periscope Photographs of Fuel Assembly 2B47 Showing That Crud, Which Appeared Adherent in 1978, Now Exhibits Flakiness and a Tendency to Peel 


\subsection{ASSESSMENT OF FUEL IMPURITIES IN BORIC ACID}

PWR coolant specifications require additions of 1 ithium hydroxide for $\mathrm{pH}$ control and borated species for fuel reactivity control. During reactor operation, the boron level is decreased to compensate for decreasing fuel reactivity. However, just before reactor shutdowns the boron level is increased to

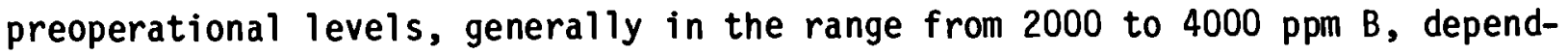
ing on specific reactor requirements. Reactor coolant and spent fuel pool waters mix during refueling operations. Therefore, to avoid boron dilution, PWR spent fuel pool operators maintain boron at levels similar to reactor co01ant specifications (Table 6). Lithium from the primary coolant also mixes into the spent fuel pools, but there is generally no requirement to control lithium levels in the pools.

While conducting SCC studies at PNL, it was observed that certain impurities occurred in some boric acid lots. To avoid complications in interpretation of the studies, boric acids from several sources were analyzed, including samples from two PWRs. Table 7 summarizes results of the analyses. The analy.ses indicate that for laboratory specimens $\mathrm{Cl}^{-}$and $\mathrm{SO}_{4}=1$ levels were; in some cases, above indicated specifications. In the two reactor-grade specimens, the $\mathrm{Cl}^{-}$and $\mathrm{SO}_{4}=$ levels were low. 
TABLE 6. PWR Spent Fuel Pool Water Quality Specifications(72)(a)

\begin{tabular}{|c|c|c|}
\hline Parameter & Normal & $\begin{array}{l}\text { Transient } \\
\text { Limits } \\
\end{array}$ \\
\hline $\mathrm{pH}$ at $77^{\circ} \mathrm{F}$ & 4.5 to $6.0^{(b)}$ & -- \\
\hline Conductivity at $25^{\circ} \mathrm{C}, \mu \mathrm{mho} / \mathrm{cm}$ & 1 to 30 & -- \\
\hline Chloride ion, ppm (max) & 0.15 & 1.5 \\
\hline Fluoride ion, ppm (max) & 0.1 & 1.5 \\
\hline Oxygen & Saturated & Saturated \\
\hline Total suspended solids, ppm (max) & 1.0 & -- \\
\hline Temperature, ${ }^{\circ} \mathrm{C}$ & 50 & 100 \\
\hline Boric acid as ppm $B(c)$ & $\begin{array}{l}0 \text { to } 2000 \\
(1950 \text { to } 2250)\end{array}$ & -- \\
\hline Activity level, $\mu \mathrm{Ci} / \mathrm{ml}$ & $\begin{array}{l}0.05 \text { (varies with } \\
\text { technical specification) }\end{array}$ & \\
\hline Solid filtration, $u m$ & 1 to 5 & -- \\
\hline $\begin{array}{l}\text { (a) May vary somewhat from pool to } \\
\text { (b) Some fuel pool pH range specif } \\
\text { range of } 4.0 \text { to } 10.6 \text {. } \\
\text { (c) Some PWR fuel pool specificati } \\
\text { range of } 0.2 \text { to } 2.0 \mathrm{ppm} \text {, corre }\end{array}$ & $\begin{array}{l}\text { lons are } 4.5 \text { to } 8.0 \text {; a few } \\
\text { liso indicate a lithium cor } \\
\text { ling to values for PWR prin }\end{array}$ & $\begin{array}{l}\text { have a } \\
\text { ation } \\
\text { ystems. }\end{array}$ \\
\hline
\end{tabular}


TABLE 7. Analysis of Boric Acids

\begin{tabular}{|c|c|c|c|c|c|c|c|c|c|c|}
\hline \multirow[b]{2}{*}{ Designation } & & & & \multicolumn{5}{|c|}{ Impurity Concentration, $\mathrm{ppm}^{(\mathrm{a})}$} & \multirow{2}{*}{$\begin{array}{l}\text { Conduc- } \\
\text { tivity, } \\
\mu \text { mho }\end{array}$} & \multirow[b]{2}{*}{$\mathrm{pH}$} \\
\hline & \multicolumn{3}{|c|}{ Description } & $\mathrm{Cl}^{-}$ & $\mathrm{SO}_{4}^{=}$ & $\mathrm{NO}_{3}^{-}$ & $\mathrm{NO}_{2}^{-}$ & $F^{-}$ & & \\
\hline HB2 & & & $99.999 \%$ & $<0.05$ & 1.47 & $<0.05$ & $<0.1$ & $<0.1$ & 12.5 & 4.60 \\
\hline HB6 & & & $99.99 \%$ & $<0.05$ & 0.88 & $<0.05$ & $<0.1$ & $<0.1$ & 12.0 & 4.65 \\
\hline HB7 & & & $99+\%$ & 1.33 & 4.9 & 0.5 & 0.99 & $<0.1$ & 32.7 & 4.71 \\
\hline HB3 & $\begin{array}{l}\text { Certified } \\
\text { A.C.S. }\end{array}$ & $\begin{array}{l}\mathrm{Cl}: \\
\mathrm{SO}_{4}:\end{array}$ & $\begin{array}{l}0.001 \% \\
0.0025 \%\end{array}$ & $<0.05$ & 0.05 & 0.1 & 0.22 & $<0.1$ & 10.25 & 4.56 \\
\hline HB5 & $\begin{array}{l}\text { Analytical } \\
\text { Reagent }\end{array}$ & $\begin{array}{l}\mathrm{Cl}: \\
\mathrm{SO}_{4}:\end{array}$ & $\begin{array}{l}0.001 \% \\
0.01 \%\end{array}$ & $<0.05$ & 0.05 & $<0.05$ & $<0.1$ & $<0.1$ & 8.9 & 4.60 \\
\hline HB4 & $\begin{array}{l}\text { Analyzed } \\
\text { Reagent }\end{array}$ & $\begin{array}{l}\mathrm{Cl}: \\
\mathrm{SO}_{4}:\end{array}$ & $\begin{array}{c}0.00009 \% \\
0.003 \%\end{array}$ & $<0.05$ & 0.05 & $<0.05$ & $<0.1$ & $<0.1$ & 8.2 & 4.66 \\
\hline HB1 & $\begin{array}{l}\text { Reagent } \\
\text { A.C.S. } \\
\text { "Crystall in }\end{array}$ & $\begin{array}{l}\mathrm{Cl}: \\
\mathrm{SO}_{4}: \\
\text { e Form" }\end{array}$ & $\begin{array}{l}0.001 \% \\
0.01 \%\end{array}$ & 0.72 & 9.2 & $<0.05$ & 0.1 & $<0.1$ & 42.5 & 5.32 \\
\hline HBO & $\begin{array}{l}\text { Reagent } \\
\text { A.C.S. } \\
\text { "Granul ar F }\end{array}$ & $\begin{array}{l}\mathrm{Cl}_{\mathrm{SO}_{4}}: \\
\mathrm{Orm}^{4}\end{array}$ & $\begin{array}{l}0.001 \% \\
0.01 \%\end{array}$ & 3.1 & 52.6 & & & & & \\
\hline HBT & Reactor gra & $d e^{(b)}$ & & $\frac{<0.05}{<0.05}$ & $\frac{0.06}{0.05}$ & $\frac{0.30}{0.12}$ & $\frac{0.67}{0.34}$ & & & \\
\hline HBT-1 & Reactor gra & & & $<0.03$ & 0.06 & $\sim 0.02$ & & $<0.1$ & & \\
\hline
\end{tabular}

(a) In solution; compared to $2000 \mathrm{ppm}$ B as boric acid.

(b) Results of duplicate analyses. 


\subsection{ASSESSMENT OF STRESS CORROSION CRACKING OF STAINLESS STEEL UNDER SPENT FUEL POOL CONDITIONS}

Two cases illustrate the susceptibility of Type 304 SS to IGSCC under spent fuel pool conditions:

A. In 1979, nine sections of pipe in the Three Mile Island Unit 1 (PWR) spent fuel pool were observed to have small through-wall cracks, (65) resulting in very slow leakage, signaled by buildup of boric acid crusts on pipe external surfaces as the moisture evaporated. In general, the cracks occurred in the redundant section of the pool coolant system, which remained stagnant for most of the time from commissioning in 1974 to observation of the cracks in 1979.

B. The upper end fitting (nozzle) separated from an irradiated PWR (Prairie Island-1) fuel assembly during handling at the spent fuel pool in December 1981 (see discussion under "Spent Fuel Handling," Section 4.1).

To provide designers and operators with a basis to avoid material and pool chemistry conditions that promote IGSCC of SS components, PNL has undertaken an investigation of the conditions that promote IGSCC at lower temperatures. Results of the studies are summarized in five publications. (73-77) In addition EPRI published a report in 1978 describing the cause of cracking in Type 304 SS piping systems at BWRs. ${ }^{(78)}$ 


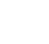




\subsection{ASSESSMENT OF STRESS CORROSION CRACKING OF STAINLESS STEEL PIPING CONTAINING STAGNANT WATER AT SPENT FUEL POOLS}

There was a general pattern in the development of small cracks in piping at the Three Mile Island Unit 1 (PWR) spent fuel pool: the cracks developed in the redundant: heat removal system. A potentially significant characteristic of that system was that the borated pool water was stagnant inside the pipes over extended periods. To investigate $\mathrm{pH}$ and oxygen changes under stagnant conditions, a stagnant pipe test was conducted.

\subsection{PROCEDURE}

The test apparatus consisted of a Type 304 SS pipe fitted with a corrosion meter, sampling ports, and a refilling system (see Figure 15). Other equipment was used to maintain the system at constant temperature and in an oxygen-free environment.

The Type $304 \mathrm{H}$ SS pipe $(91.5-\mathrm{cm}$ ID and $10.82-\mathrm{cm}$ OD) had Type 304 SS plates welded to each end. The elemental analyses of both materials are found in Table 8. The pipe volume was $8410 \mathrm{~cm}^{3}$.

Corrosion rate measurements were obtained with a laboratory corrater probe (Rohrback Model No. 6116) located near the midpoint of the pipe with two sampling ports located $15 \mathrm{~cm}$ and $22.5 \mathrm{~cm}$ below. The upper sampling port drew solutions from the center of the pipe through a $0.32-\mathrm{cm}$ ID tube (volume was $<1 \mathrm{ml})$. The lower sampling port drew solutions from near the pipe wall.

Constant temperature was maintained by wrapping heat tape around the pipe; a calibrated thermocouple was connected to the outside wall of the pipe. The thermocouple was cross-checked with a calibrated thermocouple inserted into the solution through a sampling port. The assembly was then wrapped in insulation. The solution was maintained at $28 \pm 3^{\circ} \mathrm{C}$.

The pipe was filled with a 2200-ppm B (as boric acid) solution. This solution was allowed to become air saturated (8 ppm dissolved oxygen) at $20^{\circ} \mathrm{C}$ before addition into the pipe. An analysis of the feed solution is found in Table 9. 


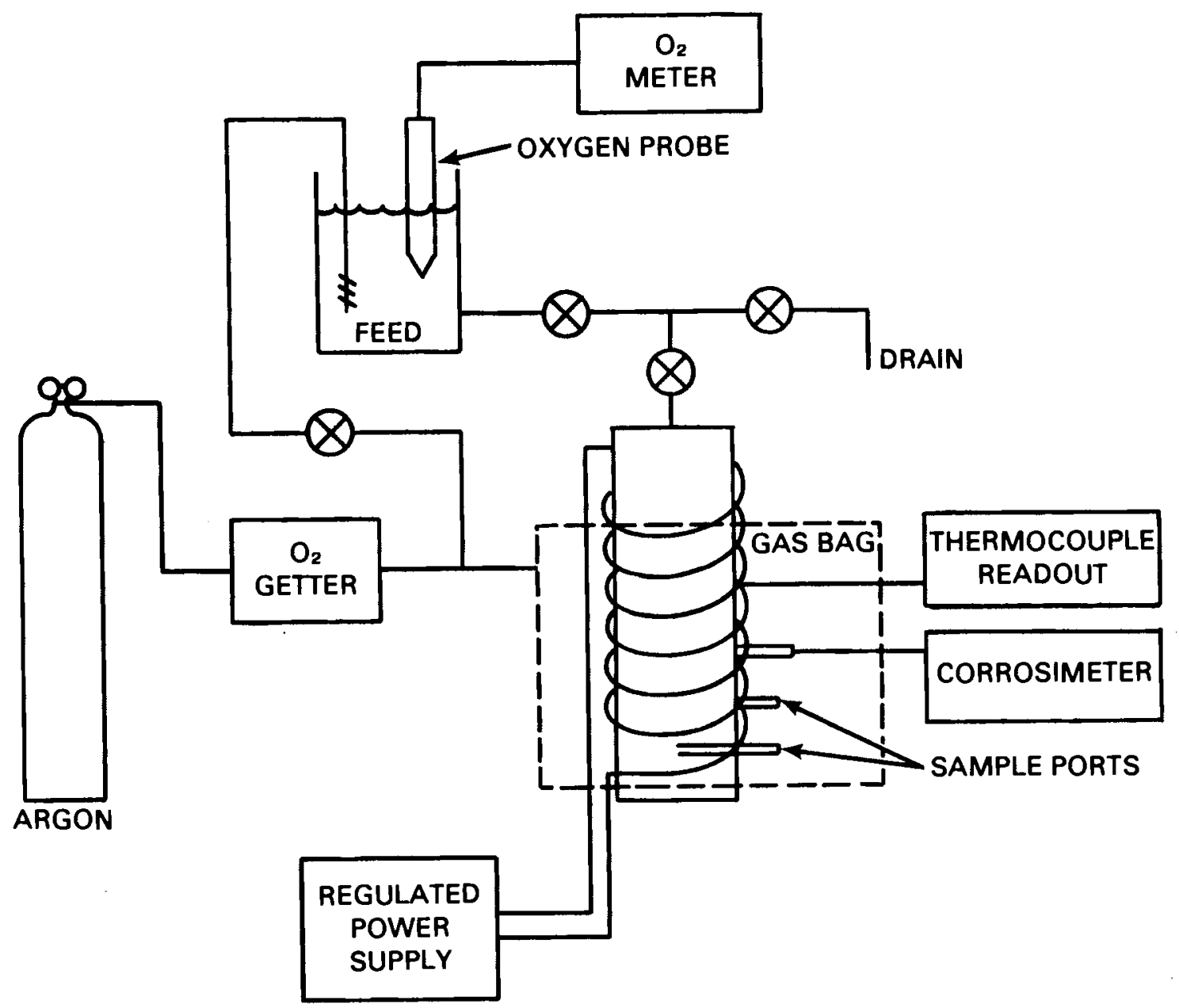

FIGURE 15. Apparatus for Conducting Stagnant Pipe Tests

TABLE 8. Chemical Analysis of Stainless Steel Pipe and End Plates

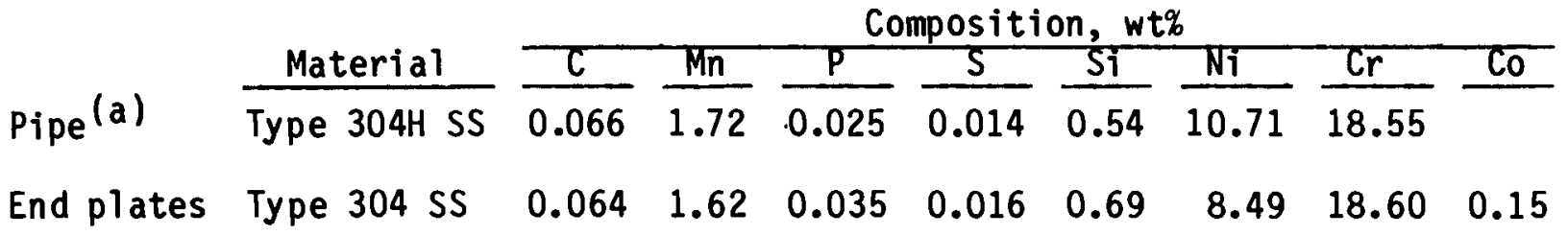

(a) Residual chloride and fluoride concentrations in the pipe (soluble halide concentration not incorporated) were $0.04 \mu \mathrm{g} / \mathrm{in} .{ }^{2}$ and $0.03 \mu \mathrm{g} / \mathrm{in} .{ }^{2}$, respectively. 
TABLE 9. Stagnant Pipe Initial Solution Chemistry

$\begin{array}{ll}\mathrm{pH} & 4.55 \\ \text { Resistivity } & \sim 48000 \mathrm{ohms}-\mathrm{cm} \\ \mathrm{Cl}^{-} \text {(ion chrom.) } & 0.3 \mathrm{ppm} \\ \mathrm{Cl}^{-} \text {(titration) } & <0.5 \mathrm{ppm} \\ \mathrm{F}^{-} \text {(ion chrom.) } & <0.25 \mathrm{ppm} \\ \mathrm{B} \text { (ICP) (a) } & 2240 \mathrm{ppm} \\ \mathrm{Ca} \text { (ICP) } & <1 \mathrm{ppm} \\ \mathrm{Fe} \text { (ICP) } & <1 \mathrm{ppm} \\ \mathrm{Na} \text { (ICP) } & <5 \mathrm{ppm} \\ \mathrm{Co} \text { (ICP) } & <0.1 \mathrm{ppm} \\ \mathrm{Cr} \text { (ICP) } & <0.2 \mathrm{ppm}\end{array}$

(a) Inductively coupled plasma.

The test was started by filling the pipe throughout the refill system and then the sampling parts to insure that no gas pockets remained in the pipe. The heat tape was then turned on. The temperature was constant by the time of the first sampling (8 days later).

During sampling, an oxygen-free argon atmosphere was maintained around the sampling ports and the sample testing by using a glove bag. Samples $(20 \mathrm{ml})$ were removed from each sampling port through a septum with a needle and syringe. These solutions were analyzed using a Chemetric Dissolved Oxygen Test Kit Model 0-12 to $\mathbf{0 . 5} \mathrm{ppm}$.

After removing and analyzing the samples, a beaker of 2200-ppm B feed solution was deoxygenated to the same dissolved oxygen concentration as found in the pipe solution and introduced into the top of the pipe. The dissolved oxygen concentration of feed solution was determined by a Yellow Springs Incorporated (YSI) dissolved oxygen meter and probe. The system was then sealed until the next sampling. 


\subsection{DATA AND RESULTS}

The dissolved oxygen concentrations of the solution at the wall and the centerline of the pipe are shown in Figures 16 and 17, respectively. From an initial concentration of $8 \mathrm{ppm}$, dissolved oxygen concentrations decreased to $4.5 \mathrm{ppm}$ and $4.0 \mathrm{ppm}$ at the wall and the centerline, respectively, after 135 days. The rate of decrease was approximately logarithmic for the first 135 days. No changes in oxygen concentration were detected from 135 days through 244 days.

Corrater measurements detected no change in the corrosion rate of the pipe. The corrosion rate was well below the 0.1 mil per year detection limit of the equipment.

The $\mathrm{pH}$ of the pipe solutions was measured at the beginning of the experiment and periodically after 161 days. The pH of the initial feed solution and the solution used to refill the pipe after sampling was 4.55. After 180 days, the $\mathrm{pH}$ of the solution withdrawn from both the wall and centerline of the pipe exhibited a linear increase (Figure 18).

\subsection{DISCUSSION}

The decrease in dissolved oxygen concentration is due to the oxidation of the stainless steel. The rate at which this oxidation decreases is roughly logarithmic, which indicates that the stainless steel is becoming more passive. The decrease in $\mathrm{O}_{2}$ concentration also decreases the corrosion potential, but this change is small, $\sim 50 \mathrm{mV} S H E$ at $28^{\circ} \mathrm{C}$ and a decrease of $4 \mathrm{ppm}$ dissolved oxygen. Oxygen has also been shown to accelerate SCC. (79-81) At $288^{\circ} \mathrm{C}$, the rate at which this acceleration increases is about 1.5 to 2 orders of magnitude between oxygen concentrations of 0.2 and $5 \mathrm{ppm}$. (82) A corresponding decrease in rate could exist at $28^{\circ} \mathrm{C}$ and may also contribute to slowing the oxygen consumption.

The oxygen concentration at the centerline was $+0.5 \mathrm{ppm}$ of oxygen greater at equilibrium than the oxygen concentration at the wall. This may be due to the depletion of $\mathrm{O}_{2}$ in the oxidation of the stainless steel and a slow diffusion of $0_{2}$ through the solution. The tube from the sample port to the 


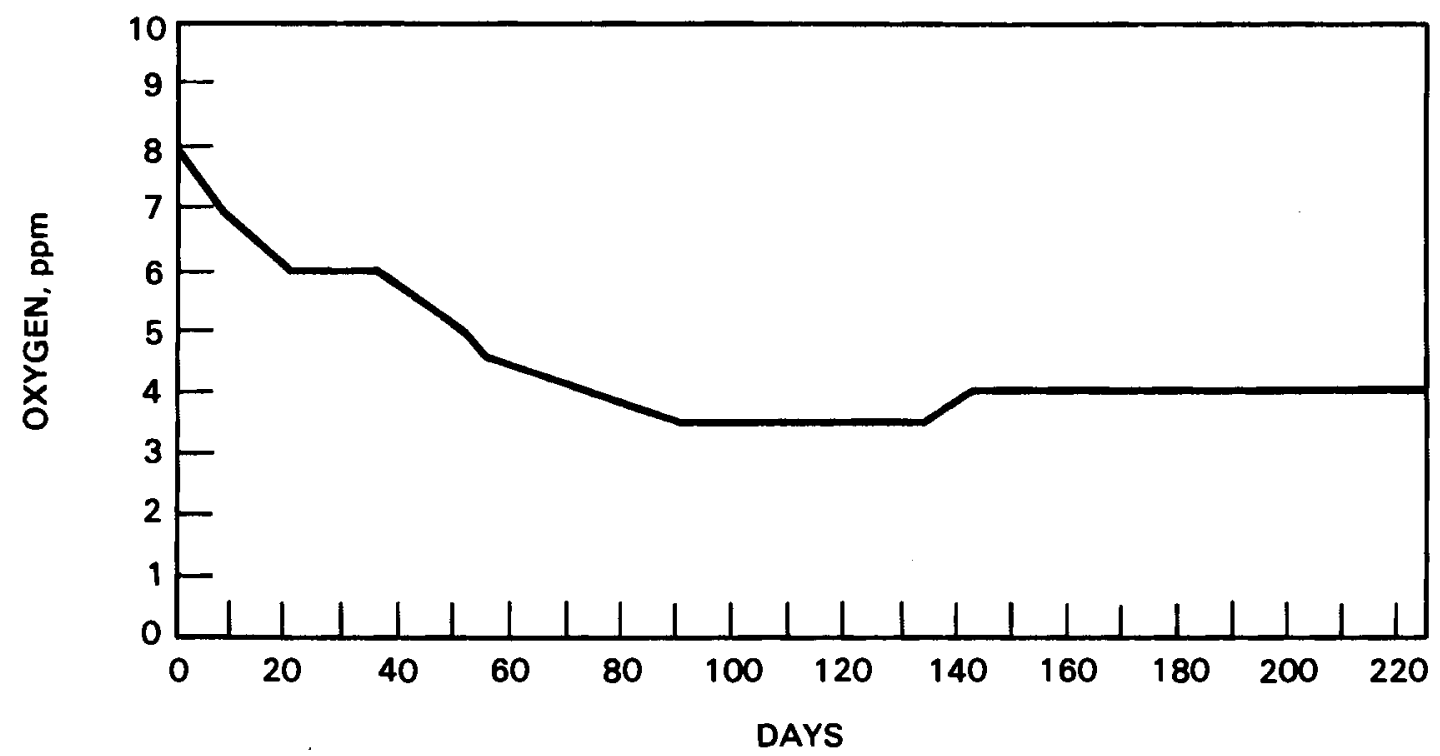

FIGURE 16. Dissolved Oxygen Concentration at the Pipe Wall

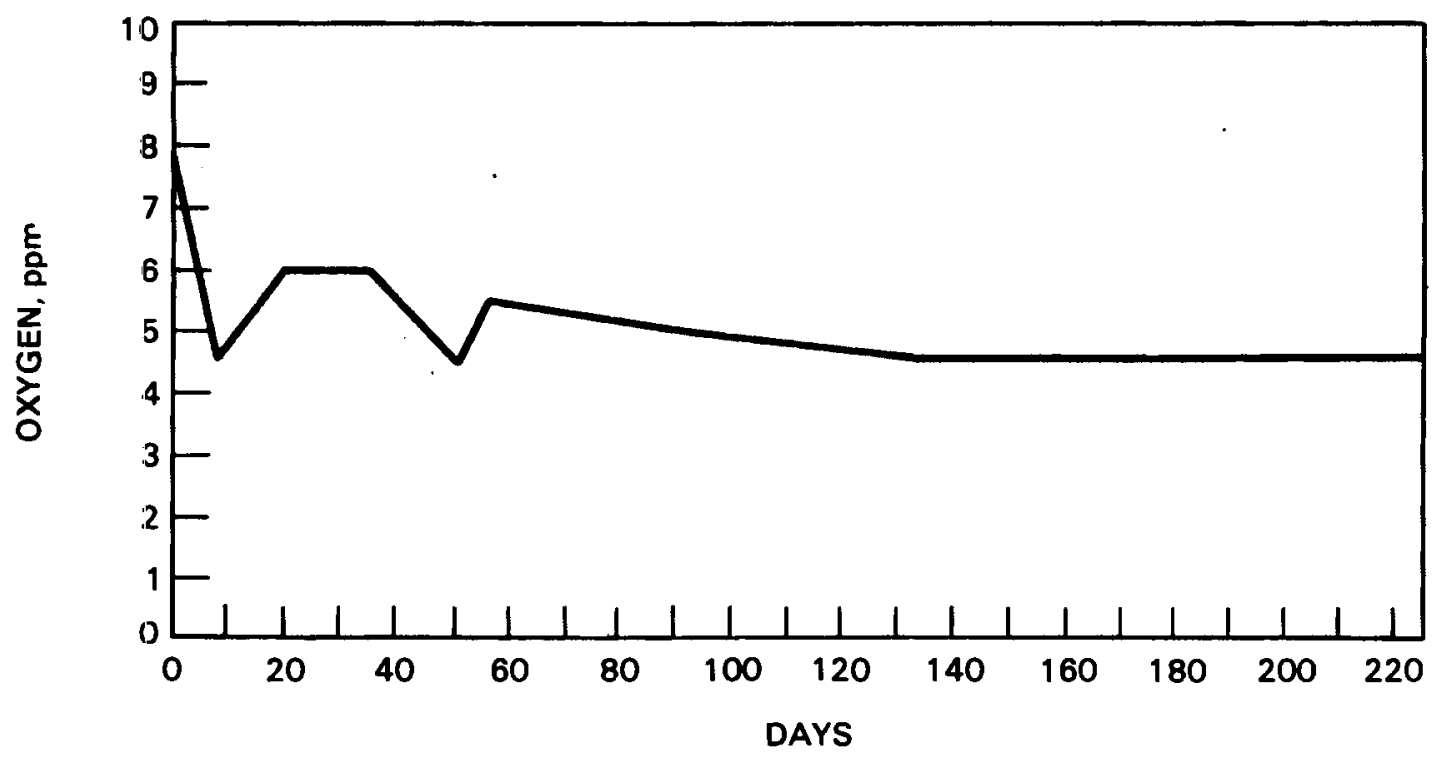

FIGURE 17. Dissolved Oxygen Concentration at the Pipe Centerline 


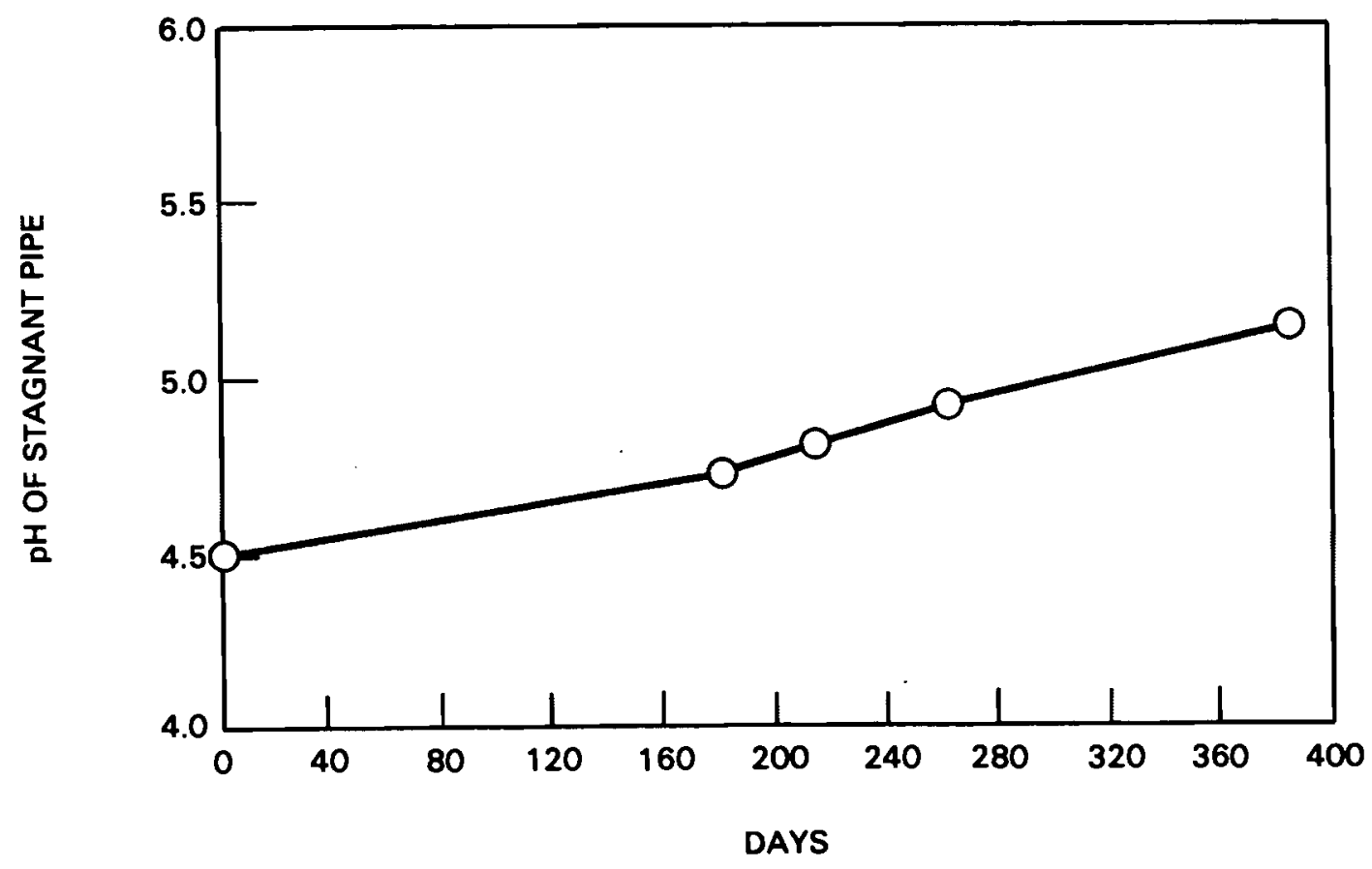

FIGURE 18. Solution pH at the Pipe Wall and Centerline

centerline of the pipe has a volume of $<1 \mathrm{~cm}^{3}$, and any change in dissolved oxygen concentration within the tube would have only a small effect on the 20-ml sample obtained. Another possibility for the higher $\mathrm{O}_{2}$ concentration is a possible leaking septum with air bubbles collecting within the tube between tests giving a high $\mathrm{O}_{2}$ concentration.

The low corrosion rate was expected, but the lack of any measurable corrosion rate was not. A corrosion data survey conducted by NACE lists a corrosion rate of Type $304 \mathrm{SS}$ in very dilute boric acid-water environment of $<2 \mathrm{mils} /$ year. ${ }^{(83)}$ The stagnant pipes located in the Three Mile Island Unit 1 spent fuel pool cooling system showed IGSCC only in sensitized weld regions and only after 22 months of service. ${ }^{(84)}$ Corrosion rates of Type 304 SS in high-purity water are known to be $<0.01 \mathrm{mils} / \mathrm{year}$.

The small change in $\mathrm{pH}$ observed after 180 days may be due to a number of causes. The Corrater probe is known to produce small amounts of $\mathrm{H}_{2}$ but was removed from service after 180 days. The production of $\mathrm{H}_{2}$ is also brought about from the oxidation of the $\mathrm{Fe}$ and $\mathrm{Cr}$ in acidic conditions. 


$$
2 \mathrm{H}^{+}+2 \mathrm{e}^{-}+\mathrm{H}_{2}
$$

Another half-reaction in the oxidation of $\mathrm{Fe}$ and $\mathrm{Cr}$ uses $\mathrm{H}^{+}$and also would increase the $\mathrm{pH}$.

$$
\mathrm{O}_{2}+4 \mathrm{H}^{+}+4 \mathrm{e}^{-} \rightarrow 2 \mathrm{H}_{2} \mathrm{O}
$$

It is probable that all of the above processes are combining to produce the $\mathrm{pH}$ change.

In sumnary, a roughly logarithmic decrease in the oxygen concentration from $8 \mathrm{ppm}$ to an equilibrium value of $-4 \mathrm{ppm}$ occurs due to the passivation of the stainless steel. This decrease was accompanied by a small increase $(0.35)$ in $\mathrm{pH}$ due to $\mathrm{H}^{+}$ion consumption in the oxidation process or $\mathrm{H}_{2}$ production by the corrater probe. The corrater probe was unable to detect any change in the corrosion rate due to lack of sensitivity ( $<0.1 \mathrm{mil} /$ year $)$. 


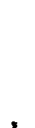

.

. 


\subsection{INSPECTION OF SPENT FUEL STORAGE FACILITY AT THE BARNWELL PLANT}

The principal materials consideration in spent fuel pools has been fuel cladding behavior. However, pools have experienced some materials and operational problems, such as liner leaks, and some cases of intergranular penetration of SS components near welds. Once spent fuel pools begin to receive irradiated fuel, there is seldom an opportunity to inspect components while the poot is dry.

The Barnwell spent fuel storage facility has a unique history. The storage facility was constructed to receive fuel for reprocessing. Construction was completed in 1974. Some of the Barnwell pools have been filled most of the time since 1974. Occasionally, however, they have been drained, providing opportunities for close inspection of the components. During a visit to Barnwell on November 11, 1982, A. B. Johnson of PNL discussed the pool history and materials and performed an inspection of the components while the pool was drained. Results of the discussions and inspection are summarized below.

\subsection{POOL HISTORY AND MATERIALS}

Figure 19 shows the pools while they were filled with water. Table 10 summarizes the Barnwell pool history and materials. Table 11 summarizes pool water chemistry control and pool operating conditions. The pool equipment has been tested by handling dummy fuel assemblies and empty fuel shipment casks.

\subsection{MATERIALS EXPERIENCE AT THE BARNWELL FUEL STORAGE FACILITY}

Since 1974, when the storage facility was first filled, to November 1982 , there were no substantial operational problems. The few materials-related observations and minor problems are outlined below.

1. When aluminum storage canisters were placed in the pool they began to evolve hydrogen gas by reaction of the metal surface with water:

$$
2 \mathrm{AT}+3 \mathrm{H}_{2} \mathrm{O}+\mathrm{Al}_{2} \mathrm{O}_{3}+3 \mathrm{H}_{2}
$$




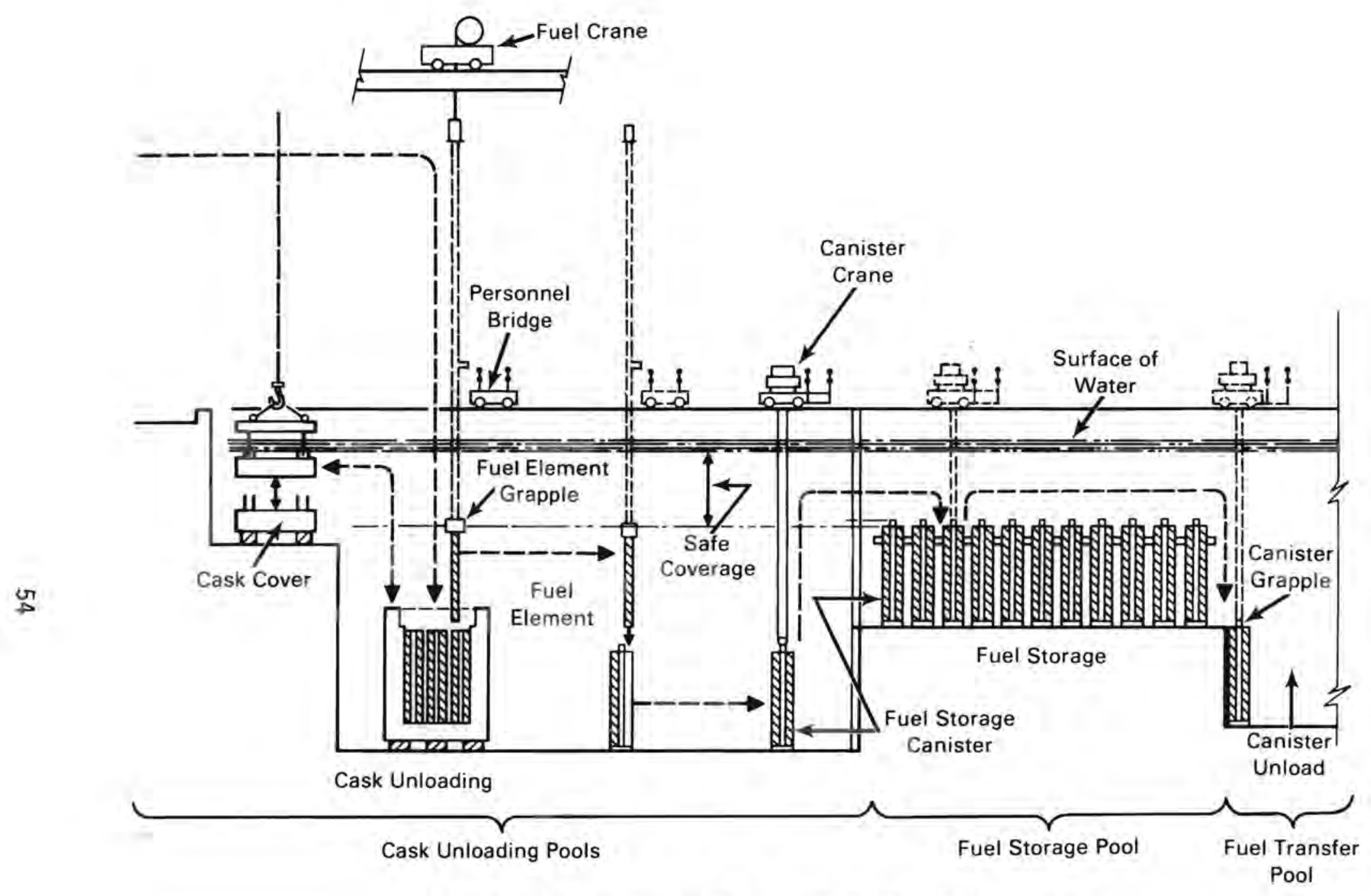

FIGURE 19. Barnwell Fuel Storage Facility. Schematic, side view; photo, top view. 


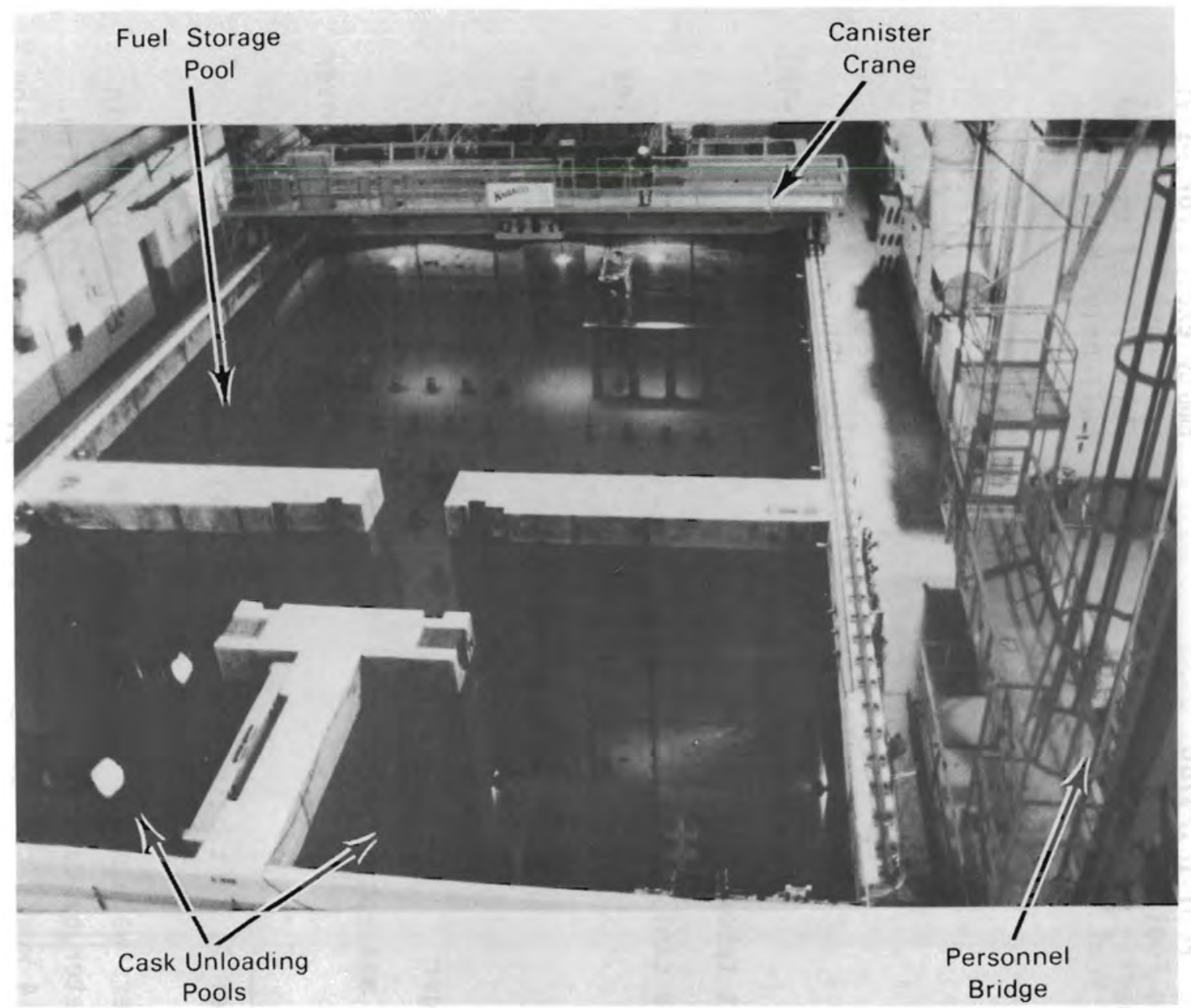

FIGURE 19. (Contd) 
TABLE 10. Barnwell Pool History and Materials

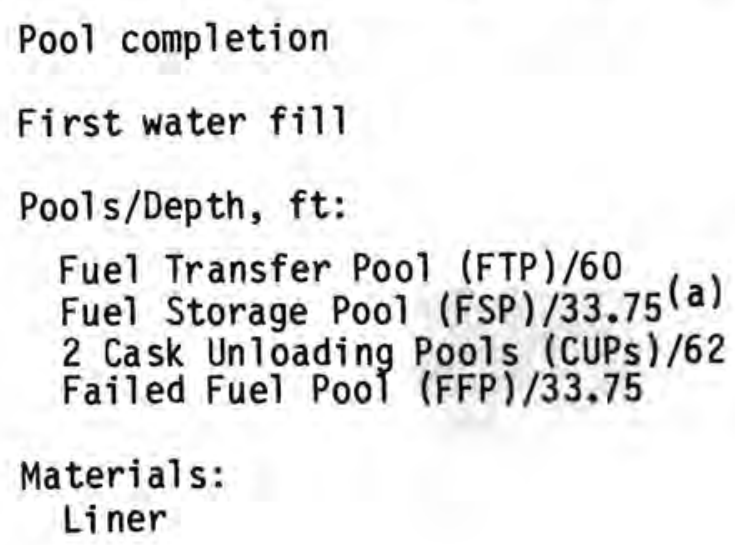

Pipes

Racks

Rack support tubes

Fuel storage canister

Gates

Heat exchanger

Cask energy absorption pad
1974

1974

Empty except for $\sim 1 \mathrm{yr}$

Ful1 most of the time

Ful1 $~ 75 \%$ of the time

Full only about $2 \mathrm{yr}$

304L SS

(3/16 in. thick;

1.2 in. thick near gates)

304L SS

Aluminum alloy (6061-T6)

Aluminum alloy

Aluminum alloy

(holds 8 PWR assemblies

or 18 BWR assemblies)

SS with inflated rubber seals

SS (plate type)

SS exterior (3-1/2-in. CS plate over al uminum honeycomb)

(a) Water level is $2 \mathrm{ft}$ below top of pool wall.

The canisters were not pre-passivated. The canisters passivated in the pool water by eventually forming a thin protective oxide film. After 3 to 4 weeks the hydrogen evolution stopped as the passivation was completed.

2. A steam line rupture occurred under the east aisle. The failed line was abandoned and a new line was run above ground. 
TABLE 11. Water Quality Control and Operating Conditions

Methods:

Ion exchange

Filter

Skimmer

Design operating temperature

Normal Operating temperature

Water control parameters

$\mathrm{pH}$

$\mathrm{Cl}^{-}$

Conductivity
Mixed bed resins

(IRN 77 and 78)

Mechanical etched disk type;

$5 \mu \mathrm{m} ; 95 \%$ efficient; 10w

maintenance; remote backwash

capability (á)

Wier type

$41^{\circ} \mathrm{C}$

$20^{\circ} \mathrm{C}$

6 to 6.5

$<1 \mathrm{ppm}$

$<2$ umho/cm

(a) 350 psi $\mathrm{N}_{2--3} \mathrm{ft}^{3}$ capacity. The backwash reservoir was undersized; should be 6 to $8 \mathrm{ft}^{3}$ capacity.

3. Moisture in the energy absorption box reacted with the carbon steel and/or aluminum, forming a hydrogen pressure which deflected the SS plate on the bottom of the pool by $\sim 3$ in. Replacement pads will be constructed entirely of SS, with relief orifices.

\subsection{AUXILIARY EQUIPMENT}

The crane is rated for 135 tons and has a 25-ton auxiliary hook. The canister crane is rated for 15 tons. There are also two gantry cranes above the CUP to handle fuel assemblies. The facility is designed to receive truck and rail casks. A conveyer that moves fuel from the fuel transfer pool to the reprocessing cell can handle 12 PWR or 24 BWR assemblies per day (5 MTU/day). SS grapples are designed to handle fuel from all prospective fuel vendors.

The water level alarm sounds at set points above and below the normal level. An automatic emergency water fill line, which feeds raw well water into 
the pool, has 6-in.-diameter pipe and delivers $500 \mathrm{gpm}$. It is activated manually from a pipe niche. There is also a 1500-gal sump.

The heat exchanger has a capacity of $1000 \mathrm{gpm}$ per unit $\left(7 \times 10^{6} \mathrm{Btu} / \mathrm{h}\right.$ per unit). There are two units. If fuel has cooled $>5 \mathrm{yr}$, the heat exchanger has sufficient capacity for a dense-racked pool. If dense racking is used, the rack support posts would be removed. The pool storage capacity currently is 350 MTU but could be increased to 1100 MTU with dense racks.

\subsection{POOL INSPECTION}

The drained pool was accessed by a personnel bucket on the crane. The inspection involved detailed visual observations on stainless steel surfaces and welds; and on aluminum racks and canisters. Figures 20 and 21 show the drained pool. The pool was vacuumed and bottom and walls were scrubbed before filling.

\subsubsection{Stainless Steel}

The pool walls and a section of the floor are shown in Figures 20 and 21. Weld runs are evident, including seam welds between floor and wall panels and at stainless steel embedments for rack supports. There was no evidence of rusting or discoloration on the SS surfaces. None of the weld areas showed discoloration, cracking, or other evidence of degradation.

\subsubsection{Aluminum Alloys}

The aluminum canister and rack in the pool had a medium gray appearance, with only minor surface pitting. There was no evidence of localized corrosion at visible locations where aluminum and SS were in contact.

Most aluminum racks and canisters had been removed to the storage yard. They were wetted in the pool for two years and had been stored in the yard for an additional five years. The surfaces were medium gray with light surface pitting. The inside surfaces of the al uminum tubes did not show evidence of localized corrosion where they were in contact with the SS posts. 


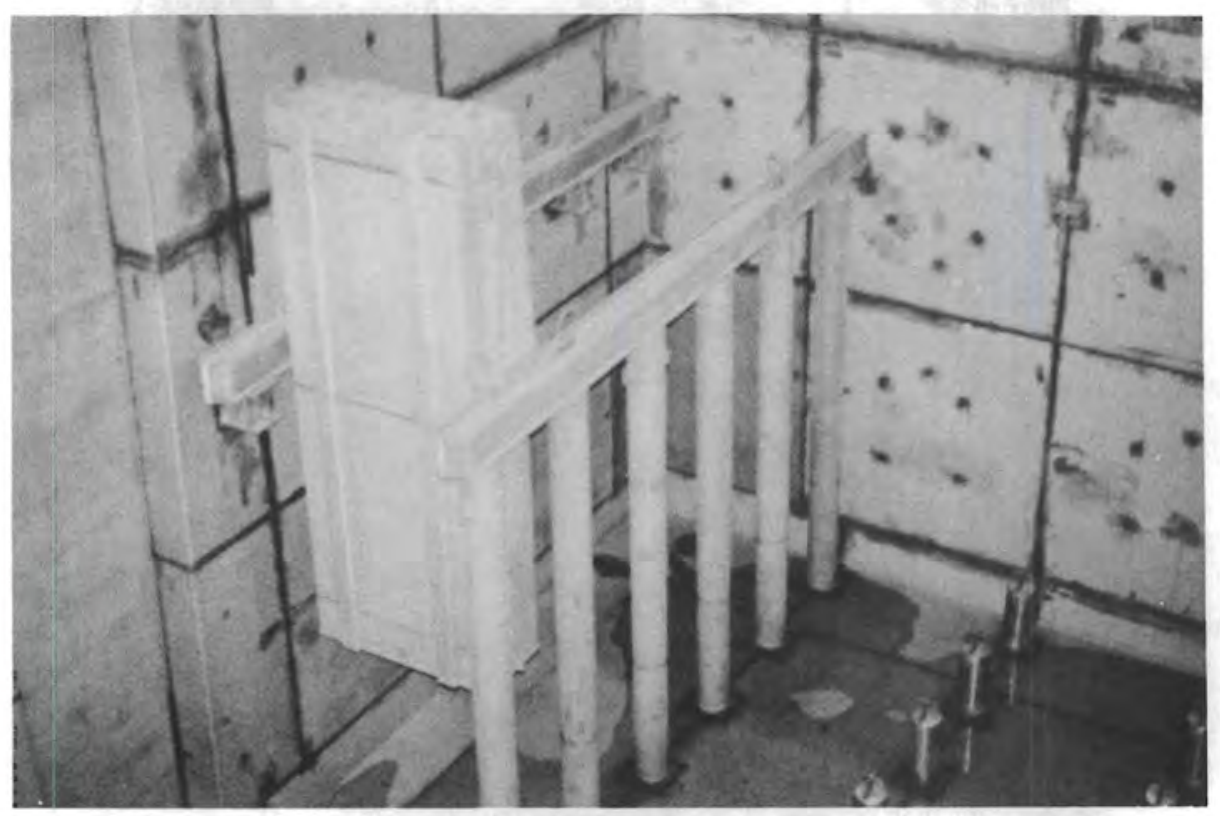

FIGURE 20. Aluminum Fuel Storage Canister on Aluminum Rack (beams and tubes). Tubes fit over SS posts; note SS seam welds on walls and floor. Dark spots on panels are plug welds to embedments to hold panels in place during welding. 


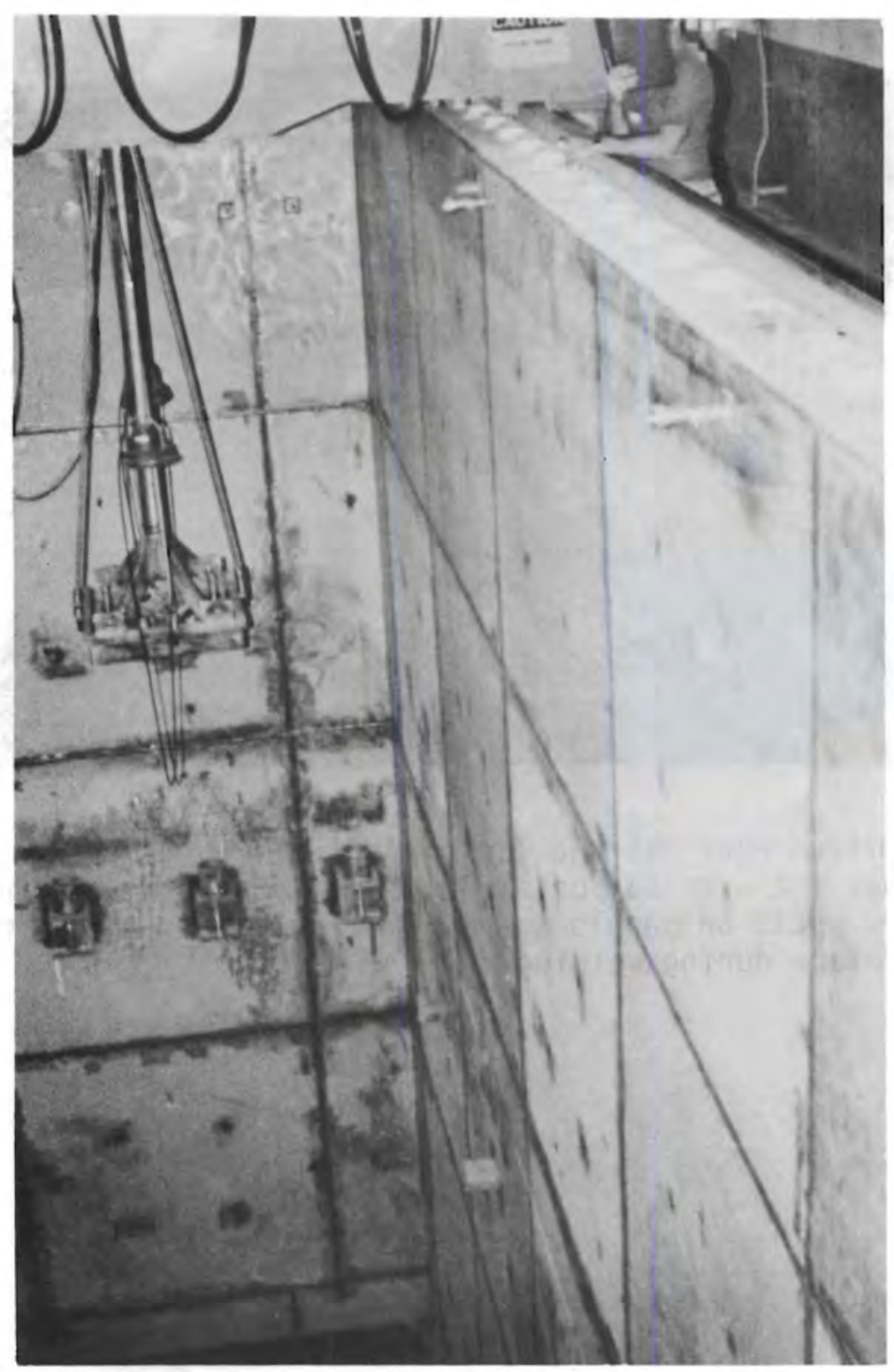

FIGURE 21. Barnwell Fuel Storage Facility with Water Removed. Note welded SS wall panels, SS rack mounts, and fuel handling crane. 


\subsection{REFERENCES}

1. Johnson, A. B., Jr., et al. September 1981. Annual Report--FY 1980: Spent Fuel and Fuel Pool Component Integrity. PNL-3868, Pacific Northwest Laboratory, Richland, Washíngton.

2. Johnson, A. B., Jr., et al. May 1980. Annual Report--FY 1979: Spent Fuel and Fuel Pool Component Integrity. PNL-3171, Pacific Northwest Laboratory, Richland, Washington.

3. "Storage of Water Reactor Spent Fuel in Water Pools--Survey of World Experience." 1982. International Atomic Energy Agency, Vienna, Austria.

4. Johnson, A. B., Jr., et al. 1983. "World Survey of Wet Storage Experience--A Summary." Presented at the IAEA Seminar on Technical and Environmental Aspects of Spent Fuel Management, September 27-30, 1983, Madrid, Spain.

5. Roberts, J.T.A., et al. 1982. "The EPRI LWR Fuel Surveillance Program." Specialists' Meeting on Examination of Fuel Assembly for Water Cooled Power Reactors. IWGFPT 12, pp. 62-78, International Atomic Energy Agency, Vienna, Austria.

6. Lang, P. M. April 1982. "Contribution to Panel Discussion on Extended Burnup---How Far? How Fast?" LWR Extended-Burnup Fuel Performance and Utilization. DOE/NE-34087, 2:8-3 through 8-5.

7. Franklin, D. G. April 1982. "The Schedule for Extending Fuel Burnup." LWR Extended Burnup--Fuel Performance and Utilization. DOE/NE-34087, 2:8-1 through 8-10.

8. Johnson, A. B., Jr., and W. J. Bailey. April 1982. "Assessment of Interim Storage of Spent High-Burnup LWR Fuel." Trans. Am. Nucl. Soc. 40:150--152.

9. Johnson, A. B., Jr., and W. J. Bailey. November 1982. "Interim Storage of Spent Extended-Burnup LWR Fuel." PNL-SA-10891, Pacific Northwest Laboratory, Richland, Washington.

10. Murphie, W. E., and P. M. Lang. April 1982. "Projected National and World Benefits to the LWR Fuel Cycle from Extended Burnup." LWR Extended Burnup--Fuel Performance and Utilization. DOE/NE-34087, 2:7-61 through 7-69.

11. Nuclear Regulatory Commission. December 1981. Regulatory Guide 1.13, Proposed Revision 2. U.S. Nuclear Regulatory Commission, Washington, D.C.

12. American Nuclear Society. 1981. Design Criteria for An Independent Spent Fuel Storage Installation (Water Pool Type). ANSI/ANS-57.7-1981 (Section $6.10 .4 .1, \mathrm{p} .18 \mathrm{1}$. 
13. Wells, A. H. November 1982. "Criticality Considerations for Consolidated Spent Fue1." Trans. Am. Nuc1. Soc. 43:422-423.

14. New England Coalition on Nuclear Power Pollution--Statement of Position in the Matter of Proposed Rulemaking on the Storage and Disposal of Nuclear Waste (Waste Confidence Rulemaking). DOE/NE-0007, Supplement 1, p. II-151, U.S. Department of Energy, September 5, 1980.

15. Shea, T. E. September 1982. Safeguards for Spent Fuel Storage with Rod Consolidation. EPRI NP-2626, ETectric Power Research Institute, PaTo ATto, CaTifornia.

16. Bailey, W. J., and A. B. Johnson, Jr. September 1982. "Current Experience with Fuel Handling and Reconstitution: Relationship to Rod Consolidation." In Proceedings of ANS International Topical Meeting on Spent Fuel Storage Options. Savannah, Georgia.

17. Lindgren, P., et a1. November-December 1981. "Fuel Reconstitution as a Method for Improving Uranium Utilization." Trans. Am. Nucl. Soc. 39:136-137.

18. Mayer, J. T., and B. C. Dudley. June 1981. "On-Site Rod Extraction from a High-Burnup Fuel Assembly." Trans. Am. Nucl. Soc. 38:727-728.

19. Klinetob, R. H., and G. H. Stevens. September 1982. "Fuel Consolidation: Applicability of Fuel Inspection and Reconstitution Experience." In Proceedings of ANS International Topical Meeting on Spent Fuel Storage Options. Savannah, Georgia.

20. "Reactor Notes." Nucleonics Week 23(4):12 (January 28, 1982), McGraw-Hi11 Inc., New York.

21. Van Swam, L.F.P., et a1. April 1982. "Poolside Fuel Assembly Reconstitution." Trans. Am. Nucl. Soc. 40:25-27.

22. Sofer, G. A. April 1982. "Technology of Burnable Absorber Reactivity Control and Other Techniques to Increase Fuel Burnup in LWR Fuel Cycles." Trans. ANS 40:183-184.

23. Haley, J., and A. A. Fesler. April 1982. "Fuel Rod Consolidation: A Key Process in Spent Fuel Storage Systems." Trans. Am. Nuc1. Soc. 40:149-150.

24. Bailey, W. J. May 1983. "Experience With Fuel Damage Caused By Abnormal Conditions in Handling and Transport." CONF-830528-Summ., D-II-18 and D-I I-19.

25. Bailey, W. J. December 1983. "Experience with Fuel Damage Caused by Abnormal Conditions in Handling and Transporting Operations." Seventh International Symposium On Packaging and Transportation of Radioactive Materials (PATRAM '83). CONF-830528, 1:802-807 (PNL-SA-10648). 
26. Bailey, W. J., et al. November 1982. Arrival Condition of Spent Fuel After Storage, Handling, and Transportation. PNL-3582, TTC-0165, Pacific Northwest Laboratory, Richtand, Washington.

27. Calabro, R. R., R.E.L. Stanford, and J. McBride. September 1982. "Utilities View the Spent Fuel Storage Problem," In Proceedings of ANS International Topical Meeting On Spent Fuel Storage Options. Savannah, Georgia.

28. "Spent-Fuel Consolidation." April 1983. Nuclear News 26(5):54-56.

29. Jewe11, C. E. November-December 1981. "Criticality Considerations of Interim Spent Fuel Storage." Trans. Am. Nuc1. Soc. 39:516-517.

30. Hong, S. Y., et al. November-December 1981. "Criticality of Normal Compacted Spent Fuel." Trans. Am. Nucl. Soc. 39:537-538.

31. Hong, S. Y., et a1. November-December 1981. "Accident Analyses of Compacted Spent Fuel." Trans. Am. Nucl. Soc. 39:538-540.

32. Pacific Gas and Electric Company, Letter to the U.S. Nuclear Regulatory Commission, Docket No. 50-133-326, June 11, 1975.

33. Pacific Gas and Electric Company, Letter to Office of Inspection and Enforcement, Region V, U.S. Nuclear Regulatory Commission, "Humboldt Bay Power Plant Unit No. 3," Docket No. 50-133-264, June 11, 1975.

34. Clark, R. A., (U.S. Nuclear Regulatory Commission), Letter to J. H. Garrity (Maine Yankee Atomic Power Company), "Safety Evaluation and Environmental Impact Appraisal Regarding Maine Yankee Spent Fuel Storage," Docket No. 50-309, June 16, 1982.

35. Barbosa, C. A. November 1980. "Construction and Cost Experience Regarding the 2nd Pool House for Spent Fuel Storage Facility in the Atucha Power Station." Spent Fuel Storage Alternatives. DOE-SR-0009, pp. 147-155.

36. Chin, S. L. November 1980. "Expanded Spent Fuel Storage Project at Yankee Atomic Electric Plant." Spent Fuel Storage Alternatives. DOE-SR-0009, pp. 327-354.

37. Boydston, L. A. December 1981. At-Reactor Storage Concepts Criteria for Preliminary As sessment. DPSP-ARF-81-6-2, E. I. du Pont de Nemours and Company, Savannah River Plant, Aiken, South Carolina.

38. Bailey, W. J., and D. C. Langstaff. 1980. "Experience with Fuel Damage from Abnormal Conditions in Handling and Transport." In Proceedings of Sixth International Symposium on Packaging and Transportation of Radioactive Materials (PATRAM 80). pp. 1113-1120. Berlin (West), Federal RepubTic of Germany, November 10-14, 1980. Published by K. 0. Storck and Co., Verlag and Druckerei GmbH, Hamburg. 
39. Vesterlund, G., and T. 0lsson. 1978. Degraderingsmeckanismer Vid Bassanglagering och Hantering av Utbrant KraftreaktorbransTe. RB 78-29, ASEAATOM, Vasteras, Sweden. (English translation: "Degradation Mechanisms During Pool Storage and Handling of Spent Power Reactor Fuel." BNWL-TR-320, Pacific Northwest Laboratory, Richland, Washington.)

40. Porcheron, J., and R. Michael. Simulation of a Fuel Handling Accident in a PWR--Experiment Piree--Handling. FRRSR-55 (VII-SFRP734-0I), undated (but 1978 or eartier).

41. Pezzello, J. A., and M. Lee. June 1973. "Fuel Performance of Indian Point Unit No. 1." Trans. Am. Nucl. Soc. 16:102-103.

42. Mayer, L. 0. (Northern States Power), Letter to NRC (Region III), "Spent Fuel Assembly D-34 Top Nozzle Event," December 30, 1981. The attachment was Licensee Event Report 81-031/01T-0 (Docket No. 50-282, Prairie Island-1).

43. Mayer, L. 0. (Northern States Power), Letter to NRC (Region III), "Update Report-Spent Fuel Assembly D-34 Top Nozzle Event," May 12, 1982. The attachment was Licensee Event Report 81-031/01X-1 (Docket No. 50-282, Prairie Island-1).

44. Brown, E. J. (NRC), Memorandum for Karl V. Seyfrit (NRC), "Fuel Assembly Degradation While in the Spent Fuel Storage Pool," October 21, 1982.

45. Seyfrit, K. V. (NRC), Memorandum for Darrell G. Eisenhut (NRC), "Fuel Assembly Degradation while in the Spent Fuel Storage Pool," October 22, 1982.

46. Denton, H. R. (NRC), Memorandum for C. J. Heltemes (NRC), "Potential Contamination of the Spent Fuel Pool and Primary Reactor System," August 16, 1983.

47. Johnson, W. V. (NRC), Memorandum for G. C. Lainas (NRC), "Safety Evaluation Report, Fuel Assembly Failure While in the Spent Fuel Pool at the Prairie Island Nuclear Generating Plant," June 17, 1983 (Docket Nos. 50-282/306).

48. Klingensmith, R. W. 1980. "Ai rborne Contamination Released During Underwater Unloading of a Failed PWR Spent Fuel Assembly." In Proceedings of Sixth International Symposium on Packaging and Transportation of RadioacEive Materials (PATRAM 80. pp. 646-653. Berlin (West), FederaT Republic of Germany, November 10-14, 1980. Published by K. 0. Storck and Co., Verlag and Druckerei GmbH, Hamburg.

49. Branscome, J., I. Kummant, and R. Laufer. 1983. "Parties Continue to Clash in Year-Long Dispute Over Transport Cask." Nucleonics Week 24(2):1-2 (January 13, 1983). McGraw-Hill Inc. New York. 
50. Office of Standards Development. December 1977. Final Environmental Statement on the Transportation of Radioactive Materials by Air and Other Modes. NUREG-0170, Vol. 1, U.S. NucTear Regulatory Commission, Washington, D.C.

51. Allen, Jr., G. C., et al. September 1982. "Spent Fuel Transportation Experience and Issues: Transshipments and Storage Casks." In Proceedings of ANS International Topical Meeting on Spent Fuel Storage Options. Savannah, Georgia.

52. Voiland, E. E. September 1982. "An Overview of Ten Years Experience at Morris Operation - An Independent Spent Fuel Storage Installation." In Proceedings of ANS International Topical Meeting on Spent Fuel Storage Options. Savannah, Georgia.

53. Duckworth, J. P. September 1982. "Spent Fuel Storage at the Western New York Service Center." In Proceedings of ANS International Topical Meeting on Spent Fuel Storage Options. Savannah, Georgia.

54. Bradley, E. R., et al. September 1981. Examination of Zircaloy-Clad Spent Fuel After Extended Pool Storage. PNL-3921, Pacific Northwest Laboratory, Richland, Washington.

55. Johnson, A. B., Jr., et al. November 1980. "Significance of Shippingport and Connecticut Yankee Fuel Examinations to Extended Water Storage of LWR Fuel." Spent Fuel Al ternatives. D0E-SR-0009, pp. 49-84.

56. Bailey, W. J., et al. 1981. "Spent Fuel Behavior in Water Pools." CORROSION/81, Preprint No. 168, National Association of Corrosion Engineers, Houston, Texas.

57. Lynam, L. R., et a1. September 1962. Fabrication Defects Observed in PWR Core 1 Blanket Fuel Rods. WAPD-TM-321, Bettis Atomic Power Laboratory, West Miffiin, Pennsylvania.

58. Henke, R. L., ed. March 1966. Summary Design Report for Melba Test in PWR Core 2 Blanket. WAPD-TM-483, Bettis Atomic Power Laboratory, West MiffTin, PennsyTvania.

59. Rosenbaum, H. S. September 1980. Demonstration of Fuel Resistant to Pellet-Cladding Interaction Phase-2 Third Semiannual Report January-June 1980. Prepared by General Electric Company for Commonweatth Research Corporation.

60. Knorr, D. B., and R. M. Pelloux. May 1981. Research on Mechanisms of Stress Corrosion Cracking in Zircaloy. PNL-3860, DOE/ET/34215-24, prepared for Pacific Northwest Laboratory by Massachusetts Institute Technology, Cambridge, Massachusetts.

61. Wood, J. C. 1973. "Factors Affecting Stress Corrosion Cracking of Zircaloy in Iodine Vapour." J. Nucl. Mater. 45:105-122. 
62. Hunt, C.E.L., J. C. Wood, and A. S. Bain. 1979. Long-Term Storage of Fuel in Water. AECL-6577, Chalk River Nuclear Laboratories, Ontario, Canada.

63. Hillner, E. 1974. "Corrosion and Hydriding Performance of Zircaloy Tubing After Extended Exposure in the Shippingport Pressurized Water Reactor." Zirconium in Nuclear Applications. ASTM STP 551, American Society for Testing and Materials, pp. 449-462.

64. Hillner, E. January 1980. Corrosion and Hydriding Performance Evaluation of Three Zircaloy-2 Clad FueT AssembTies After Continuous Exposure in PWR Cores 1 and 2 at Shippingport, Pennsylvania. WAPD-TM-1412, Bettis Atomic Power Laboratory, West Miffiin, Pennsylvania.

65. Giacobbe, F. S. 1981. "Examination, Evaluation, and Repairs of Stress Corrosion Cracking in a PWR Borated Water Piping System." CORROSION/81, Preprint No. 164, National Association of Corrosion Engineers, Houston, Texas.

66. Bailey, W. J., and M. Tokar. December 1982. Fuel Performance Annual Report for 1981. PNL-4342, NUREG/CR-3001, U.S. Nuclear Regulatory Commission, Washington, D.C.

67. Mayer, L. 0. (Northern States Power), Letter to NRC (Region III), "Spent Fuel Assembly D-34 Top Nozzle Event," Dec. 30, 1981. The attachment was Licensee Event Report 81-031/01T-0 (Docket No. 50282, Prairie Island-1).

68. Mayer, L. 0. (Northern States Power), Letter to NRC (Region III), "Update Report--Spent Fuel As sembly D-34 Top Nozzle Event," May 12, 1982. The attachment was Licensee Event Report 81-031/01X-1 (Docket No. 50282, Prairie Island-1).

69. Langstaff, D. C., et al. September 1982. Examination of Stainless SteelClad Connecticut Yankee Fuel Assembly S004 After Storage in Borated Water. PNL-3828, Pacific Northwest Laboratory, Richland, Washington.

70. Pasupathi, V., and R. W. Klingensmith. November 1981. Investigation of Stainless Steel Clad Fuel Rod Failures and Fuel Performance in the Connecticut Yankee Reactor. EPRI NP-2119, Electric Power Research Institute, Palo Alto, California.

71. Johnson, A. B., Jr., et a1. 1982. "Materials Behavior in Interim Storage of Spent Fuel." Trans. Am. Nucl. Soc. 43:314-315.

72. Johnson, A. B., Jr. September 1977. Behavior of Spent Nuclear Fuel in Water Pool Storage. BNWL-2256, Pacific Northwest Laboratory, Richland, Washington.

73. Divine, J. R., et al. 1981. "Overview of Spent Fuel Pool Materials Studies at Pacific Northwest Laboratory." CORROSION/81, Preprint No. 171, National Association of Corrosion Engineers, Houston, Texas. 
74. Jones, R. H., A. B. Johnson, Jr., and F. S. Gi acobbe. 1981. "Assessment of Stress Corrosion Cracking in a Spent Fuel Pool Pipe." CORROSION/81, Preprint No. 165, National Association of Corrosion Engineers, Houston, Texas.

75. Bruemmer, S. M., et al. April 1982. "Evaluating the Intergranular SCC Resistance of Sensitized Type 304 Stainless Steel in Low Temperature Water Environments." In Proceedings of ASTM Symposium on Environment-Sensitive Fracture: Comparison of Test Methods, National Bureau of Standards.

76. Jones, R. H., A. B. Johnson, Jr., and S. M. Bruemmer. 1981. "An Evaluation of Stress Corrosion Cracking of Sensitized 304 SS in Low Temperature Borated Water." In Proceedings of Conference on Environmental Degradation of Engineering Materials, Virgina Polytechnic Institute, Blacksburg, Virgina, p. 321.

77. Bruemmer, S. M., and A. B. Johnson, Jr. 1982. "Effect of Chloride, Thiosulfate and Fluoride Additions on the IGSCC Resistance of Type 304 Stainless Steel in Low Temperature Water." In Proceedings of the International Symposium on Environmental Degradation of Materials in Nuclear Power Systems--Water Reactors, Myrtle Beach, South Carolina, August 22-25, 1983.

78. Hanneman, R. E., et al. December 1978. "Cause of Cracking--Evaluation of Performance Margin Between Different Diameter Type 304 Stainless Steel Piping Systems." Studies on AISI Type 304 Stainless Steel Piping Weldments for Use in BWR Applications. EPRI NP-944, Electric Power Research Institute, Palo Alto, California.

79. Clarke, W. L., and G. M. Gordon. 1973. "Investigation of Stress Corrosion Cracking Susceptibility of $\mathrm{Fe}-\mathrm{Ni}-\mathrm{Cr}$ Alloys in Nuclear Reactor Water Environments." Corrosion 29(1)1.

80. Indig, M. May 1977. Evaluation of Near-Term BWR Piping Remedies. NEDC-21.463-2, General ETectric Company, San Jose, California.

81. Anderson, P. A., and D. J. Duquette. August 1980. "The Effects of Dissolved Oxygen, Chloride Ion and Applied Potential on the SCC Behavior of Type 304 Stainless Steel in $290^{\circ} \mathrm{C}$ Water." Corrosion 36(8):409-415.

82. Cheng, C.F. 1975. "Intergranular Stress-Assisted Corrosion Cracking of Austenitic Alloys in Water-Cooled Nuclear Reactors." J. Nucl. Mater. $56: 11-33$

83. Norman Hamner. 1974. Metals Section, Corrosion Data Survey. 5th Ed. National Association of Corrosion Engineers, Houston, Texas.

84. Giacobbe, F. S. 1963. Examination, Evaluation and Repairs of Stress Corrosion Cracking in a PWR Borated Water Piping System. General Public Utility Nuclear Corporation, Reading, Pennsylvania. 


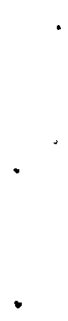


APPENDIX

PUBLICATIONS 
APPENDIX

PUBLICATIONS

Publications and presentations resulting from the Wet Storage Task of the Spent Fuel Integrity Project are listed below:

Bailey, W. J., A. B. Johnson, Jr., and D. C. Langstaff. 1981. "Spent Fuel Behavior in Water Pools." CORROSION/81, Preprint No. 168, National Association of Corrosion Engineers, Houston, Texas.

Bailey, W. J., and A. B. Johnson, Jr. 1982. "Current Experience with Fuel Handling and Reconstitution: Relationship to Rod Consolidation." In Proceedings of ANS International Topical Meeting on Spent Fuel Storage Options, September 27-29, 1982, Savannah, Georgia.

Bailey, W. J., et al. November 1982. Arrival Condition of Spent Fuel After Storage, Handling, and Transportation. PNL-3582, Pacific Northwest Laboratory, Rich and, Washington.

Bradley, E. R., et al. September 1981. Examination of Zircaloy-Clad Spent Fuel After Extended Pool Storage. PNL-3921, Pacific Northwest Laboratory, Richland, Washington.

Bruemmer, S. M., and A. B. Johnson, Jr. 1982. "Effect of Chloride, Thiosulfate and Fluoride Additions on the IGSCC Resistance of Type 304 Stainless Steel in Low Temperature Water." In Proceedings of the International Symposium on Environmental Degradation of Materials in Nuclear Power Systems-Water Reactors, August 22-25, 1983, Myrtle Beach, South Carolina.

Bruemmer, S. M., et al. 1982. "Evaluating the Intergranular SCC Resistance of Sensitized Type 304 Stainless Steel in Low Temperature Water Environments." In Proceedings of ASTM Symposium on Environment-Sensitive Fracture: Comparison of Test Methods. National Bureau of Standards.

Divine, J. R., et al. 1981. "Overview of Spent Fuel Pool Materials Studies at Pacific Northwest Laboratories." CORROSION/81, Preprint No. 171, National Association of Corrosion Engineers, Houston, Texas.

Johnson, A. B., Jr. 1977. Behavior of Spent Nuclear Fuel in Water Pool Storage. BNWL-2256, Pacific Northwest Laboratory, Richland, Washington.

Johnson, A. B., Jr. 1977. "Spent Fuel Integrity in Water Pool Storage." Trans. Am. Nucl. Soc. 27:488-489. 
Johnson, A. B., Jr. 1977. "Testimony for California Energy Resources Conservation and Development Commission." BNWL-SA-6213, summarized in Summary of Testimony Regarding Spent Fuel Assembly Storage, California Public Resources Code 25524.1, March 10, 1977, Docket No. 76-NL-1 and 76-NL-3, issued May 26, 1977.

Johnson, A. B., Jr. 1978. "Basis for Projecting Spent Fuel Behavior in Water Pool Storage." Presented at AIME Annual Meeting, February 26-March 2, 1978, Denver, Colorado.

Johnson, A. B., Jr. 1978. "Impacts of Reactor-Induced Fuel Cladding Defects on Spent Fuel Storage." Presented at OECD/NEA Symposium on Storage of Spent Fuel Elements, June 20-30, 1978, Madrid, Spain. (Available from Organization for Economic Cooperation and Development, Paris.)

Johnson, A. B., Jr. 1978. "Spent Fuel Behavior in Water Pools." NUREG/CP0448, presented at NRC-IAEA Spent Fuel Storage Meeting, February 28-March 2, 1978, Bethesda, Maryland.

Johnson, A. B., Jr. 1978. "Spent Fuel Integrity in Pool Storage." Presented at Back End of the LWR Fuel Cycle, March 19-23, 1978, Savannah, Georgia.

Johnson, A. B., Jr. 1978. Testimony for the Trojan Reactor Spent Fuel Pool Modification Hearing (January 1978) and District Court Hearing, May 1978.

Johnson, A. B., Jr. 1978. "Utility Spent Fuel Storage Experience." Presented at the American Nuclear Society-Executive Conference on Spent Fuel Policy and Its Implications, April 2-5, 1978, Buford, Georgia.

Johnson, A. B., Jr. 1979. "Spent Fuel Storage Experience." Nucl. Tech. 43:165-173.

Johnson, A. B., Jr. 1979. "Testimony for Zion Reactor Spent Fuel Pool Hearing." PNL-SA-7735, Pacific Northwest Laboratory, Richland, Washington.

Johnson, A. B., Jr. September 1980. "Cross Statement Testimony." Section II, C.2-5, DOE/NE-0007, Supp1. 1.

Johnson, A. B., Jr., et al. 1980. Annual Report--FY 1979, Spent Fuel and Fuel Pool Component Integrity. PNL-31\%, Pacific Northwest Laboratory, Richland, Washington.

Johnson, A. B., Jr., et al. 1980. "Significance of Shippingport and Connecticut Yankee Fuel Examinations to Spent Fuel Storage." Spent Fuel Storage

Alternatives. DOE-SR-0009. November 17-21, 1980, Las Vegas, Nevada.

Johnson, A. B., Jr., et al. September 1981. Annual Report--FY 1980: Spent Fuel and Fuel Pool Component Integrity. PNL-3868, Pacific Northwest Laboratory, Richland, Washington. 
Johnson, A. B., Jr., et al. November 1982. "Materials Behavior in Interim Storage of Spent Fue1." Trans. Am. Nuc1. Soc. 43:314-315.

Johnson, A. B., Jr., et al. 1983. "Behavior of Spent Nuclear Fuel and Storage System Components in Interim Storage." PNL-SA-11197, Pacific Northwest Laboratory, Richland, Washington.

Johnson, A. B., Jr., et a1. 1983. "World Survey of Wet Storage Experience--A Summary." Presented at the IAEA Seminar on Technical and Environmental Aspects of Spent Fuel Management, September 27-30, 1983, Madrid, Spain.

Johnson, A. B., Jr., and W. J. Bailey. 1980. Scientific Basis for Confidence That Spent Fuel Can Be Stored Until Geologic Disposal Facilities Are Available. PNL-SA-8197, contribution to Section IV, "Extended Storage Assessment" of the DOF: Draft for NRC Confidence Rulemaking, DOE/NE-0007, April 15, 1980, Pacific Northwest Laboratory, Richland, Washington.

Johnson, A. B., Jr., and W. J. Bailey. April 1982. "Assessment of Interim Storage of Spent High-Burnup LWR Fuel," Trans. Am. Nucl. Soc. 40:150-152. (Proceedings of International ENS/ANS Conference held in Brussels, Belgium, Apri1 26-30, 1982.)

Johnson, A. B., Jr., and W. J. Bailey. November 1982. "Interim Storage of Spent Extended-Burnup LWR Fue1." PNL-SA-10891, Pacific Northwest Laboratory, Richland, Washington.

Johnson, A. B., Jr., W. J. Bailey, and E. R. Gilbert. 1982. "Behavior of $\mathrm{VO}_{2}$ Fuel in Wet and Dry Interim Storage." Presented at the American Ceramics Society Symposium on Spent Fuel Storage, April 25-27, 1983, Chicago, Illinois.

Johnson, A. B., Jr., R. H. Jones, and B. Griggs. November 1979. Three-Mile Island No. 1 Spent Fuel Pool System Pipe Cracking Analysis. PNL-3102, Pacific Northwest Laboratory, Richland, Washington.

Jones, R. H., A. B. Johnson, Jr., and S. M. Bruemmer. 1981. "An Evaluation of Stress Corrosion Cracking of Sensitized 304 SS in Low Temperature Borated Water." In Proceedings of Conference on Environmental Degradation of Engineering Materials, Virginia Polytechnic Institute, Blacksburg, Virginia, p. 321.

Jones, R. H., A. B. Johnson, Jr., and F. S. Giacobbe. 1981. "Assessment of Stress Corrosion Cracking in a Spent Fuel Pool Pipe." CORROSION/81, Preprint No. 165, National Association of Corrosion Engineeers, Houston, Texas.

Kustas, F. M., et al. 1981. Investigation of the Condition of Spent Fuel Pool Components. PNL-3513, Pacific Northwest Laboratory, Richland, Washington.

Langstaff, D. C., et al. September 1982. Examination of Stainless Steel-Clad Connecticut Yankee Fuel Assembly S004 After Storage in Borated Water.

PNL-3828, Pacific Northwest Laboratory, Richland Washington. 


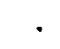

- 


\section{DISTRIBUTION}

No. of

Copies

OFFSITE

4 Nuclear Waste Policy Act

Project Office

U.S. Department of Energy

Washington, DC 20545

R. H. Bauer

J. H. Carlson

M. J. Lawrence

K. A. Klein

R. D. Nel son

DP 331-MS 4B026

U.S. Department of Energy

1000 Independence Ave., S.W.

Washington, DC 20585

27 DOE Technical Information Center

W. L. Godfrey

BE Inc.

P.0. Box 145

New Ellenton, SC 29809

G. Yarrow

Babcock \& Wilcox

1990 N. California St.

Suite 400

Walnut Creek, CA 94596

V. Pasupathi

Battelle Columbus Laboratories

505 King Avenue

Columbus, $\mathrm{OH} 43201$

B. A. Rawles

Battelle Memorial Institute

Office of Nuclear Waste Isolation

505 King Avenue

Columbus, $\mathrm{OH} 43201$
No. of

Copies

Bechtel National, Inc.

P.0. Box 3965

San Francisco, CA 94119

Black \& Veatch

P.0. Box 8405

Kansas City, MO 64114

R. G. Clough

Boston Edison Company

25 Braintree Hill office Park

Braintree, MA 02184

Burns and Roe Industrial Services Corp.

P.0. Box 667

Paramus, NJ 07652

Burns and Roe Pacific, Inc.

601 Williams Blvd.

Richland, WA 99352

CYGNA Energy Services

600 Atlantic Ave.

24th Floor

Boston, MA 02210

L. H. Martin

Carolina Power and Light Company

P.0. Box 1551

Raleigh, NC 27602

C. K. Anderson

Combustion Engineering, Inc.

1000 Prospect Hill Road

Windsor, CT 06095

A. Gianopoulos

Commonwealth Edison Company

FNW-Fuel Dept.

P.0. Box 767

Chicago, IL 60690 
No. of

Copies

T. J. Marz

Consumers Power Company

1945 West Parnall Road

Jackson, MI 49201

T. L. Bradley

Duke Power Company

P.0. Box 33189

Charlotte, NC 28242

EG\&G Services, Inc.

P.0. Box 2266

Idaho Falls, ID 83401-0566

Ebasco Services Incorporated

Two World Trade Center

New York, NY 10048

R. W. Lambert

Electric Power Research Institute

3412 Hillview Avenue

Palo Alto, CA 94303

S. Craig

Florida Power and Light Company

P.0. Box 529100

Miami, FL 33152

FLUOR Engineers, Inc.

Advanced Technology Division

P.0. Box C-11944

Santa Anna, CA 92711-1944

J. D. Rollins

GNS

340 Six Branches Court

Roswe11, GA 30076

E. E. Voiland

General Electric Company

Nuclear Fuel \& Services Division

7555 E. Collins Road

Morris, IL 60450
No. of

Copies

W. L. Dobson

Gilbert/Commonweal th

P.0. Box 1498

Reading, PA 19603

J. A. McBride

E. R. Johnson Associates, Inc.

11702 Bowman Green Dr.

Reston, VA 22090

Morrison-Knudson Company, Inc. P.0. Box 7808

Boise, ID 83729

NUS Corporation

910 Clopper Road

Gaithersburg, MD 20878

NUTECH

$6835 \mathrm{Via}$ Del Oro

San Jose, CA 95119

J. A. Nevshemal

P.0. Box 195

Muscatine, IA 52761

E. Pitruzzella

Northeast Utilities

P.0. Box 270

Hartford, CT 06101

T. Silverburg

Northern States Power Company

414 Nicollet Mall

Minneapolis, MN 55401

J. V. Houston, Jr.

Nuclear Assurance Corp.

5720 Peachtree Parkway

Norcross, GA 30092

Nuclear Energy Services, Inc.

Shelter Rock Road

Danbury, CT 06810 
No. of

Copies

G. A. Tidrick

Pacific Gas \& Electric Company 45/10/D28

77 Beale St.

San Francisco, CA 94106

Ralph M. Parsons Company

100 West Walnut Street

Pasadena, CA 91124

R. H. Logue

Philadelphia Electric Company

2301 Market Street N2-1

Philadelphia, PA 19101

M. Litterman

Portland General Electric

Company

121 S.W. Salmon Street

Portland, OR 97204

W. R. Yario

Power Authority of State of New York

10 Columbus Circle

New York, NY 10019

R. K. Reynolds

Raymond Kaiser Engineers

300 Lakeside Drive

P.0. Box 23210

Oakland, CA 94623

A. A. Fuierer

Rochester Gas and Electric Corporation

89 East Avenue

Rochester, NY 14649

Rockwell International

Corporation

Energy Systems Group

8900 De Soto Ave.

Canoga Park, CA 91304

Sanders \& Thomas Inc.

11 Robinson St.

Pottstown, PA 19464
No. of

Copies

R. M. Jefferson

Sandia National Laboratories

Transportation Technology Center

P.0. Box 5800

Albuquerque, NM 87185

Sargent \& Lundy

55 East Monroe Street

Chicago, IL 60603

Science Applications, Inc.

P.0. Box 2351

La Jolla, CA 92038

E. C. - Rodgers

Southern California Edison Company

P.0. Box 800

Rosemead, CA 91770

S. H. Popper

Stone \& Webster Engineering Corporation

P.0. Box 2325

Boston, MA 02107

J. B. Moegling

Tennessee Valley Authority

404 Krystal Bldg.

Chattanooga, TN 37443

M. E. Mason

Transnuclear, Inc.

One Worth Broadway

White Plains, NY 10601

United Engineers

P.0. Box 8223

Philadelphia, PA 19101

J. P. Roberts

U.S. Nuclear Regulatory

Commission

NMSS

Washington, DC 20555 
No. of

Copies

2 D. W. Reisenweaver

U.S. Nuclear Regulatory Commission

Washington, DC 20555

H. W. Wilson

Virginia Electric Power Company P.0. Box 26666

Richmond, VA 23261

J. H. Saling

Westinghouse Electric Corp.

P.0. Box 10864

Pittsburgh, PA 15236

A. R. Hak 1

Westinghouse Electric Corp.

Waste Technology Services

Division

P.0. Box 708

Nevada Test Site

Mercury, NV 89023

J. B. Wright

Westinghouse Electric Corp.

Waste Technology Service

Divison

P.0. Box 10864

Pittsburgh, PA 15236

ONSITE

7 DOE Richland Operations Office

P. A. Craig (4)

J. L. Daily

H. E. Ransom

J. J. Schreiber

Hanford Engineering Development
No. of

Copies

Kaiser Engineers Hanford Co.

G. P. Osborne

Rockwell Hanford Company

C. L. Brown

50 Pacific Northwest Laboratory

W. B. Andrews

W. J. Bailey (5)

J. 0. Barner

R. A. Clark

B. M. Cole (5)

R. M. Fleischman

J. F. Fletcher

M. D. Freshley

E. R. Gilbert

R. J. Guenther

R. J. Hall

C. R. Hann

P. E. Hart

G. M. Hoiter

A. B. Johnson, Jr. (5)

W. S. Kelly

D. K. Kreid

R. C. Liikala

H. D. Massey

J. L. MCElroy

J. F. Nesbitt

D. F. Newman (5)

D. R. Oden

K. J. Schneider

R. L. Shaub

M. J. Sherbin

R. I. Smith

Publishing Coordination (2)

Technical Information (5)

R. E. Einziger 